\title{
The Standard of the Reasonable Person in Determining Negligence - Comparative Conclusions
}

\section{P.E.R}

Pioneer in peer-reviewed, open access online law publications

Author

Raheel Ahmed

Affiliation

University of South Africa

Email

ahmedr@unisa.ac.za

Date Submission

14 July 2020

Date Revised

26 March 2021

Date Accepted

26 March 2021

Date published

19 April 2021

Editor Dr G Viljoen

How to cite this article

Ahmed R "The Standard of the Reasonable Person in Determining Negligence - Comparative Conclusions" PER / PELJ 2021(24) - DOI

http://dx.doi.org/10.17159/17273781/2021/v24i0a8631

Copyright

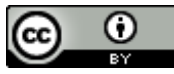

DOI

http://dx.doi.org/10.17159/1727$3781 / 2021 / v 24 i 0 a 8631$

\begin{abstract}
The standard of the reasonable person or its equivalent, in general, is used in many jurisdictions to determine fault in the form of negligence. Although the standard is predominantly objective it is also subjective in that the subjective attributes of the person against whom the standard applies as well as the subjective circumstances present at the time of the delict or tort lend themselves to an objective-subjective application. In South African law, before a person can be judged according to the standard of the reasonable person, the person must first be held accountable. If a person cannot be held accountable, then the standard does not apply at all.
\end{abstract}

The general standard of the reasonable person cannot be applied to children, the elderly, persons with physical disabilities, persons with mental impairments or experts. Therefore, depending on the subjective attributes of the person against whom the standard is being applied, the standard may have to be adjusted accordingly. The general standard of the reasonable person would be raised when dealing with experts, for instance, and lowered when dealing with persons with physical disabilities.

This contribution considers whether the current application of the standard of the reasonable person in South African law is satisfactory when applied generally to all persons, no matter their age, experience, gender, physical disability and cognitive ability. The application of the standard of the reasonable person in South African law is compared to the application of the standard of the reasonable person or its equivalent in the United Kingdom, the United States of America and France. Just as South African law applies the standard of the reasonable expert to experts, this contribution explores whether the South African law should be developed to use similar adjusted standards when dealing with children, the elderly, persons with physical disabilities and so on.

\section{Keywords}

American law; bonus pater familias; children; delict; English law; fault; faute; French law; mental impairment; negligence; physical disability; reasonableness; reasonable expert; reasonable person; South African law; standard; the elderly; tort. 


\section{Introduction}

In all the jurisdictions that will be discussed in this contribution, namely South Africa, France, the United Kingdom and the United States of America, the standard of the "reasonable person" or terms equivalent to it is used in determining fault in the form of negligence. ${ }^{1}$

In a previous contribution, ${ }^{2}$ the reasons for the choice of the jurisdictions mentioned above and the fundamental differences and similarities between these legal systems were explained. South African and French law use a generalising approach, in that all the elements of a delict must be present before liability in delict will follow, whereas in the United Kingdom and the United States of America, a system of separate torts is found with the torts having their own requirements, the main tort ${ }^{3}$ being the tort of negligence. ${ }^{4}$ It was also explained in this previous contribution ${ }^{5}$ that there has lately been uncertainty surrounding the role of reasonableness in the South African law of delict. ${ }^{6}$ This also applies to the standard of the reasonable person, in that it is used not only in determining negligence but also in determining other elements of delictual or tort liability. ${ }^{7}$ In this contribution the focus will be on the application of the standard of the reasonable person in determining negligence only.

Raheel Ahmed. LLB LLM LLD (University of South Africa). Admitted Attorney, Conveyancer and Notary of the High Court of South Africa. Associate Professor, Department of Private Law, University of South Africa. Email: ahmedr@unisa.ac.za. ORCID: https://orcid.org/0000-0001-6179-2361. This contribution is based on material taken from various chapters of my LLD thesis The Explicit and Implicit Influence of Reasonableness on the Elements of Delictual Liability. This study was made possible as a result of the "Academic Qualification Improvement Programme" grant awarded to me by my employer, the University of South Africa.

1 See Minister of Safety and Security $v$ Carmichele 20043 SA 305 (SCA) 325, Sea Harvest Corporation (Pty) Ltd v Duncan Dock Cold Storage (Pty) Ltd 20001 SA 827 (SCA) 839-840 (where the courts stated that "the true criterion for determining negligence is whether in the particular circumstances the conduct complained of falls short of the standard of the reasonable person"), Kruger $v$ Coetzee 19662 SA 428 (A) 430 and Mukheiber $v$ Raath 19993 SA 1065 (SCA) 1077 with regard to South African law; Peel and Goudkamp Winfield and Jolowicz on Tort 143 and the authority cited therein with regard to English law; Dobbs, Hayden and Bublick Hornbook on Torts 214 and the authority cited therein with regard to American law, and GalandCarval "Liability for Damage Caused by Others" 90-93 as well as the authority cited therein with regard to French law.

2 Ahmed 2019 PELJ 2-5.

The terms "tort" and "delict" are used synonymously.

Ahmed 2019 PELJ 2-5.

Ahmed 2019 PELJ 2.

This current contribution is the fourth contribution in a series of contributions based on the influence of reasonableness on the elements of delictual liability.

This will be discussed further in a forthcoming contribution. 
In the South African law of delict, the standard of the reasonable person and the reasonable expert are often encountered in determining negligence. ${ }^{8}$ There is, however, as will be pointed out further on, ${ }^{9}$ a lack of authority in general on how the standard should be applied to persons with physical disabilities or impairments and the elderly. In spite of this lack of authority, it is possible to demarcate the manner in which the standard should be applied in South African law by using a common sense approach and taking into account how French and Anglo-American law ${ }^{10}$ apply the standard. Furthermore, in South African law it is trite that the reasonable person test is applied to a child or minor. French law also applies the equivalent of the reasonable person standard albeit in an attenuated form, ${ }^{11}$ while the other jurisdictions discussed in this contribution do not. ${ }^{12}$ In order to conclude whether the application of the general standard of the reasonable person in determining negligence in South African law is suitable for all persons (no matter their age, gender, disability, impairment etcetera) it is necessary to analyse and consider the similarities and differences between South Africa and other jurisdictions in the application of the standard of the reasonable person (or its equivalent) in determining negligence. ${ }^{13}$ It is also necessary to consider how the standard is adjusted when dealing with children, the elderly, persons with physical disabilities, persons with mental impairments and experts.

In South African and French law, when determining fault in the form of negligence, the standard of the reasonable person is encountered under the element of fault or faute respectively. In English and American law (from here on referred to as Anglo-American law), the standard of the reasonable person is encountered under the requirement of a "breach of a duty of care", in the tort of negligence. The "breach of a duty of care" requirement questions whether the actor's conduct strayed from the standard of the reasonable person and was negligent. ${ }^{14}$

In this contribution the focus will be on the nature of the standard of the reasonable person as a yardstick in determining negligence and how this

$8 \quad$ See Loubser and Midgley Law of Delict 154, 171-172; Neethling and Potgieter Law of Delict 169, 173-176; Van der Walt and Midgley Principles of Delict 237, 269-270; Boberg Law of Delict 274, 346.

$9 \quad$ In para 3.1 below.

10 The mix of English and American law.

11 See para 3.4 below.

12 See para 3.2-3.3 below.

13 France and the United Kingdom in particular have influenced many legal systems in the world. See Van Dam European Tort Law 9.

14 See Ahmed 2019 THRHR 140-145 as well as the authority cited therein with regard to a more detailed explanation of the "duty of care concept". 
yardstick is adjusted depending on the subjective attributes of the person against whom the test is being applied. The tests of reasonable foreseeability of harm, reasonable preventability of harm and the circumstances present at the time of the alleged wrongdoing as well as contributory negligence will not be discussed except in a peripheral manner when discussing the nature of the standard of the reasonable person.

For comparative purposes in this contribution, the base standard of the reasonable person was taken to refer to the standard that is applied to a gender-neutral adult over eighteen years of age without any physical disabilities or mental impairments. To begin with, some general observations will be made related to the standard of the reasonable person from Anglo-American Common Law. This will be followed by a discussion of the adaptation of the base standard of the reasonable person in South African, Anglo-American and French law, depending on the subjective attributes of the actor. Thereafter, a summary of the comparative conclusions will be provided, concluding with some possible recommendations for South African law.

\section{General observations related to the standard of the reasonable person from Common Law}

The concept of the bonus pater familias (the good family father) ${ }^{15}$ originated in Roman law and is synonymous with the term, "the reasonable person" or its equivalent as used nowadays. The reasonable person standard is normative, ${ }^{16}$ flexible and value-based. ${ }^{17}$ Members of the community generally assume that fellow members will comply with a "uniform standard of conduct" and a member's conduct must conform to the "ideals and standards of a particular community". ${ }^{18}$ The standard has been criticised ${ }^{19}$ inter alia for being favourable to men ${ }^{20}$ and specific classes of persons. When the standard is interpreted by adjudicators, there is a tendency at times for them to reflect their subjective views in judgments. ${ }^{21}$ Nevertheless, as a standard it is useful and illustrates the law's devotion to justice. ${ }^{22}$ In

As used in the French law of delict.

Miller and Perry 2012 NYU L Rev 323.

Van der Walt and Midgley Principles of Delict 237, 243.

Van der Walt and Midgley Principles of Delict 237.

See Moran Rethinking the Reasonable Person.

See Bender $1988 \mathrm{~J}$ Leg Ed 3ff. Bender (20-25) traces how initially the concept was formulated in the masculine form, illustrating bias. Also see Martin 1994 Anglo-Am L Rev 334, 342-345; Mullender 2005 MLR 682.

$21 \quad$ Mullender 2005 MLR 683.

22

Mullender 2005 MLR 681-682. 
trying to establish exactly what the reasonable person standard is, a number of academic writers' views will be referred to.

Artosi $^{23}$ states that the reasonable person is a well-known, fictional, abstract character supposed to be endowed with the morals, virtues and reasoning ability which society expects from its members. Hart ${ }^{24}$ submits that the standard of reasonableness "created space for ordinary moral reasoning". Zipursky ${ }^{25}$ submits that the standard of the reasonable person is used as a decision-making tool for adjudicators, allowing them to make determinations of reasonableness with ease. Weinrib ${ }^{26}$ submits that the reasonable person standard outlines the limit between the defendant's freedom to act as he or she wishes and "the plaintiff's interest in security by treating certain risks as unreasonable." Ripstein ${ }^{27}$ states that the standard encompasses the idea of fair terms with regard to social interactions where there are dividing risks that accompany everyday acceptable human conduct. Generally, a person who fails to meet the required benchmark of acceptable behaviour may be held liable for the harm caused to others. ${ }^{28}$

According to Holmes, ${ }^{29}$ the community generally expects individuals to forgo their peculiarities to a certain extent. Prosser, ${ }^{30}$ along the same lines, submits that one who lives in a community must conform to the community's standards and be responsible for the harm or loss. There is no leniency or excuse for not applying the standard of the reasonable person where a particular person is unintelligent, emotionally unstable, uneducated and easily excitable or has any other personal idiosyncrasies. ${ }^{31}$

Moran's ${ }^{32}$ views on the various understandings of reasonableness in the reasonable person standard are rather interesting. After studying the role of

Artosi "Reasonableness" 69. Also see Neethling and Potgieter Law of Delict 169176.

Hart Concept of Law 132-133. See Moran Rethinking the Reasonable Person 281. Zipursky 2015 U Pa L Rev 2149.

Weinrib Tort Law 47. See Moran Rethinking the Reasonable Person 174.

Ripstein "Reasonable Persons in Private Law" 255, 258.

See Zipursky 2004 Fordham L Rev 1929, who refers to Ripstein's concept of the reasonable person as "objective and value laden". Ripstein holds views similar to those of Keating 1996 Stan L Rev 329-332, 337-341, which draws on Rawls' idea of reasonableness.

Holmes Common Law 86, referred to by Moran Rethinking the Reasonable Person 162.

Keeton et al Prosser and Keeton on the Law of Torts 153, referred to by Moran Rethinking the Reasonable Person 163.

See Van der Walt and Midgley Principles of Delict 241.

Moran Rethinking the Reasonable Person. Extensive references to the views of Moran in this part of the contribution as well as under para 3.2 below reflect the fact that she is the only researcher, as far as can be determined, who has written in depth 
the reasonable person standard extensively in a number of common law jurisdictions, she submits that the reasonable person is regarded as an ordinary, normal, human being. His or her conduct must be "accepted as normal and general by other members of the community in similar circumstances." 33 Moran ${ }^{34}$ makes a distinction between normal and reasonable behaviour. The distinction is irrelevant in instances where normal behaviour is considered reasonable behaviour. She ${ }^{35}$ points out that in practice, the reasonable person standard is fraught with different understandings of what is normal, natural and ordinary. Moran ${ }^{36}$ submits that in practice it is normal and thus reasonable for young boys to be inattentive to their own and others' safety, while with young girls this is not normal, and it would therefore be unreasonable for a young girl to be imprudent. Moran ${ }^{37}$ refers to Gilligan, ${ }^{38}$ who found substantial gender differences in moral reasoning, whereby "girls use a voice of relation, of care and connection, which differs from boys' emphasis on abstract rules and ... ethics of justice." 39 A woman, ${ }^{40}$ young girl ${ }^{41}$ and a mentally impaired

on this topic and, in addition, her views are persuasive. Professor Elspeth Reid (from the University of Edinburgh) advised me from the outset that any research undertaken on the reasonable person or reasonableness must include material from Moran's monograph.

Moran Rethinking the Reasonable Person 133. Moran (133) quotes Flemming Law of Torts 119-120. See the later edition, Sappideen and Vines Fleming's The Law of Torts 128-129. See further authority cited by Moran $134 \mathrm{fn}$. 15 with reference to customs and the community.

$34 \quad$ Moran Rethinking the Reasonable Person 7.

35 Moran Rethinking the Reasonable Person 9, 17.

$36 \quad$ Moran Rethinking the Reasonable Person 9.

37 Moran Rethinking the Reasonable Person 178.

$38 \quad$ Gilligan In a Different Voice 1982.

39 Moran Rethinking the Reasonable Person 178 in reference to Gilligan's findings.

See the extensive authority cited by Moran Rethinking the Reasonable Person 199 fn. 1. Moran (199-231) points out that in a criminal context with regard to provocation, self-defence and sexual assault, the standard of reasonableness applies differently to women (also see Donovan and Wildman 1981 Loy LA L Rev 435).

Moran Rethinking the Reasonable Person 110-111 and Welke Recasting American Liberty 94 refer to Michigan Central Railroad v Hassenyer 48 Mich 205, 209-210 (SC 1882) involving the death of a thirteen year-old who was killed when an engine backed up as she was crossing the railway track. Cooley J's instructions to the jury was that however negligent the railroad company had been, the jury must consider the standard of ordinary care that she should have had with regard to herself. To Cooley J, care referred to being more cautious than a male - "a woman would be likely to be more prudent, careful and particular in many positions and in the performance of many duties than a man would. She would, for example, be more vigilant and indefatigable in her care of a helpless child; she would be more particular to keep within the limits of absolute safety when the dangers which threatened were such as only great strength and courage could venture to encounter." Moran (111125), in support of the unequal treatment, refers to a number of cases highlighting that the reasonableness of conduct of girls is judged more harshly than that of boys. 
person $^{42}$ are held to a harsher standard of reasonableness. ${ }^{43} \mathrm{~A}$ more relaxed standard is, however, generally recommended for the elderly members of the community. ${ }^{44}$

In respect of a mentally impaired person, ${ }^{45}$ Moran ${ }^{46}$ explains that the impairment is regarded as an abnormality, an "idiosyncrasy or peculiarity". $\mathrm{He}$ or she is not regarded as a full member of the community. The mentally impaired are judged according to the uniform standard of the reasonable person despite their cognitive and intellectual shortcomings. ${ }^{47}$ Moran refers to the following reasons supplied for applying this uniform standard to the mentally impaired: that it is in line with the idea of the general welfare of the community; it deters dangerous conduct; ${ }^{48}$ even though it does impose a form of strict liability, it can be justified as the conduct involves heightened risk and is deemed unreasonably risky conduct; ${ }^{49}$ on grounds of equality and fairness, the victim who sustains harm as a result of the defendant's mental impairment should be compensated; 50 and it would be burdensome for the courts to try and establish the extent of a person's mental capacity. ${ }^{51}$

42 In Anglo-American law.

$43 \quad$ Moran Rethinking the Reasonable Person 14.

$44 \quad$ Moran Rethinking the Reasonable Person 24-26, 138. She refers to Barett III 1984 $J$ Marshall $L$ Rev 873, who proposes a relaxed standard for the elderly. Also see para 3.4 below in respect of French law with regard to a person over the age of seventy years, and para 3.3 below in respect of American law where contributory negligence cannot be applied to an institutionalised elderly person.

45 In terms of Anglo-American Common law.

46 Moran Rethinking the Reasonable Person 9, 147-154 illustrates how historically women were also not considered as full citizens. Their liberty was restrained and they were generally considered the weaker sex. Moran (183) refers to Vogel "Is Citizenship Gender-specific?" 62 where historically the following groups inter alia lacked legal capacity: children; women; the insane; slaves and serfs. Certain religious groups such as Jews and Catholics as well as certain ethnic groups were denied full legal rights and membership. Moran (184-197) refers to the inequality applied to people from different racial groups and people with different financial standings.

47 Moran Rethinking the Reasonable Person 13. However, in South African law, the standard is applied only if the person can be held accountable. See para 3.1 below. See the discussion by Moran Rethinking the Reasonable Person 31-39 with regard to the deterrence and compensation rationale.

49 Moran Rethinking the Reasonable Person 41-42, 45.

50 Moran Rethinking the Reasonable Person 137-138 refers to Fleming Law of Torts 126 (see later edition Sappideen and Vines Fleming's The Law of Torts 132) citing Adamson v Motor Vehicle Insurance Trust 195758 WALR 56 (SC) and Alexander and Szas 1967 Notre Dame L Rev 26, who state that mental illness is a deviation "from normal moral and social standards". One must, however, take into account the year in which the contribution was written by latter authors. Moran Rethinking the Reasonable Person 28. 
Moran ${ }^{52}$ distinguishes between a person without objectively viewed mental or physical impairments and a person with physical disabilities. To illustrate by way of an example, she refers to the English case, Vaughan $v$ Menlove. ${ }^{53}$ In this case, the defendant built a hay rick close to the boundary of his property. He was informed on numerous occasions, over a period of time, that the manner in which it was built was dangerous but he nonetheless decided to "chance it". The hay subsequently caught alight, spread to the plaintiff's land and caused damage to two of the plaintiff's cottages. The defendant tried to avoid liability by alleging that he was acting to the best of his cognitive abilities. The court applied an objective standard of a man of ordinary prudence, dismissing his subjective cognitive shortcomings. Moran ${ }^{54}$ refers to the English case, Roberts $v$ Ramsbottom, ${ }^{55}$ where the driver suffered a stroke while driving and was found negligent even though the court acknowledged that he was not able to appreciate that he should have stopped. This came close to strict liability, which contradicts fault liability of the tort of negligence itself. ${ }^{56} \mathrm{She}^{57}$ points out, however, that this was revisited by the Court of Appeal in Mansfield $v$ Weetabix, 58 where the court took into account the driver's hypoglycaemic state which he was unaware of and found him not to have been negligent.

Moran ${ }^{59}$ illustrates that common sense reasoning is applied in assuming what is normal, natural and reasonable. She ${ }^{60}$ submits that there is a connection between the freedom to act, blameworthiness and prevention of harm. She ${ }^{61}$ points out that Rawls, Holmes and Honoré all require that the actor has the capacity to prevent harm. Normal, natural behaviour is considered as non-culpable conduct.

By applying the standard of the reasonable person, Moran ${ }^{62}$ submits that sometimes there is inequality which does not adhere to corrective justice. She ${ }^{63}$ does not propose the adoption of a subjective approach, which in her

\footnotetext{
$52 \quad$ Moran Rethinking the Reasonable Person 19.

$53 \quad$ Vaughan $v$ Menlove 18373 Bing NC 468; 132 ER 490 (CP).

$54 \quad$ Moran Rethinking the Reasonable Person 20-21.

55 Roberts $v$ Ramsbottom 19801 All ER 7 (QBD).

56 Moran Rethinking the Reasonable Person 39, however, refers to the idea that the reasonable person standard does in a way apply strict liability as the person's shortcomings are disregarded.

57 Moran Rethinking the Reasonable Person 22.

$58 \quad$ Mansfield $v$ Weetabix 19881 WLR 1263.

59 Moran Rethinking the Reasonable Person 131-135.

60 Moran Rethinking the Reasonable Person 175.

61 Moran Rethinking the Reasonable Person 177, 241-248.

62 Moran Rethinking the Reasonable person 11, 52, 56.

63 Moran Rethinking the Reasonable Person 206.
} 
opinion would result in discrimination. She ${ }^{64}$ submits that reasonableness is interpreted as ordinariness with reference to customary norms. This is problematic, as what is regarded as ordinary or customary leads to discrimination inter alia against persons with mental impairments, girls and women. The result, she submits, is that the standard "operates as an (unjustifiable) standard of ordinariness rather than as a (justifiable) standard of reasonableness". 65 In order to ensure that the reasonableness standard lives up to its egalitarian promise, she proposes that the objective reasonableness standard be understood as "appropriate attentiveness to the interests of others" and unreasonable conduct as "culpable indifference to the interests of others". ${ }^{66}$ In short, she proposes removing the person from the standard as her answer to the objective egalitarian approach. ${ }^{67}$

She applies her approach to Mansfield $v$ Weetabix, ${ }^{68}$ stating that the defendant was not indifferent to the interests of others, and his conduct was not blameworthy or negligent. ${ }^{69}$ She applies the same approach to Roberts $v$ Ramsbottom, ${ }^{70}$ concluding that due to the sudden stroke suffered by the defendant, he was not indifferent to the interests of others. Therefore, his conduct was not objectively unreasonable. ${ }^{71}$ In Vaughan $v$ Menlove, ${ }^{72}$ where the defendant claimed limited intelligence, his conduct showed selfpreference for his own interests and indifference to others' interests, which was culpable. ${ }^{73}$

In response to Moran's proposal Mullender ${ }^{74}$ submits that she underestimates the tools available in negligence law which would assist in the adaptation of the law according to her proposal. In Mansfield $v$ Weetabix, ${ }^{75}$ Mullender ${ }^{76}$ submits that the defendant did not act, hence he was not a wrongdoer. In terms of corrective justice, the defendant should not be held liable. Mullender ${ }^{77}$ submits that there is no problem with the

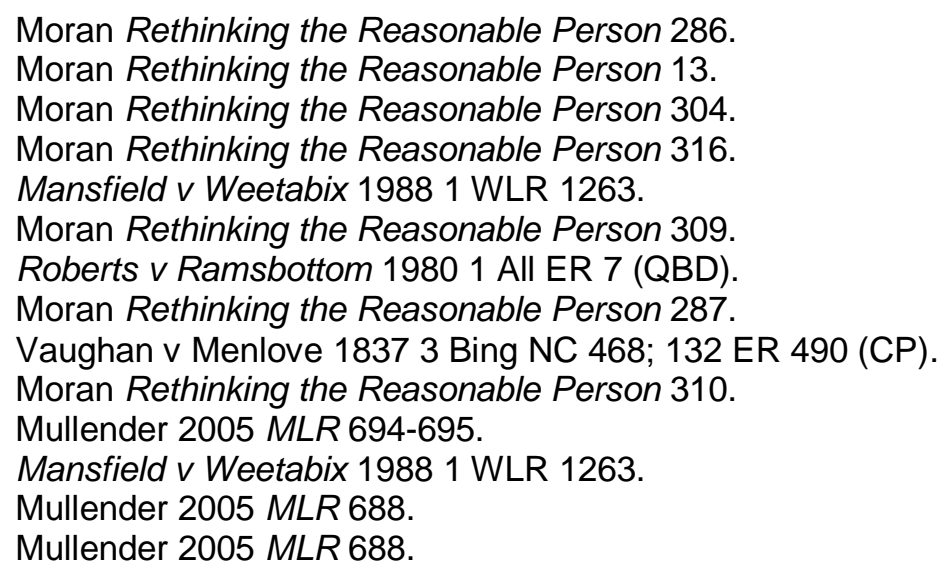


concept of reasonableness itself but that there is a failure on the part of some adjudicators to dispense justice within the scope of reasonableness.

Moran ${ }^{78}$ most certainly points out the inequality of the application of the standard of the reasonable person. One can also agree with Mullender's view $^{79}$ that there is no problem with the concept of reasonableness but that the problem lies with the adjudicator's interpretation of it.

From the general observations made above, it is apparent that there are some broad strokes one can make when it comes to understanding the adjudicators' application of the standard of the reasonable person. A person's peculiarities and cognitive shortcomings may not be considered as mitigating factors when applying the standard, but a physical impairment or condition which one is unaware of, such as in the case of Mansfield $v$ Weetabix, ${ }^{80}$ may result in the exoneration of liability. Children and the elderly, due to their age-related cognitive abilities, may be held to a more relaxed standard of reasonableness. In Anglo-American law as well as in French law, ${ }^{81}$ the conduct of a mentally impaired person is judged according to the standard of the reasonable person despite his or her cognitive and intellectual shortcomings. Moran points out ${ }^{82}$ that there is a distinction between normal, ordinary and reasonable behaviour. Women and young girls are generally held to a harsher standard of reasonableness than men and young boys. From these general observations we can now look more closely at the adaptation of the standard of the reasonable person, depending on the specific subjective attributes of the alleged wrongdoer or actor in Anglo-American, South African and French law.

\section{The adaptation of the base standard of the reasonable person depending on the subjective attributes of the actor}

\subsection{South Africa (South African law)}

In South African law, the concept of "accountability" is a prerequisite for fault. ${ }^{83}$ The actor must have the mental capacity to be at fault at the time of

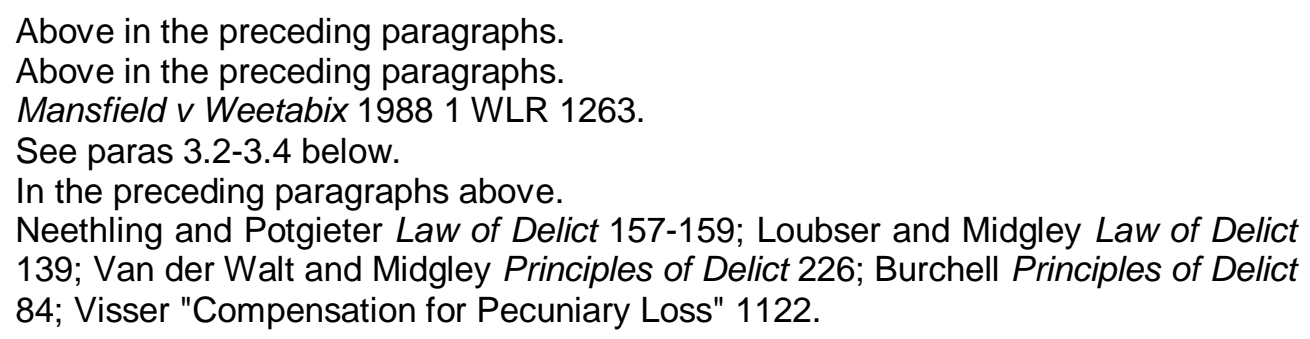
139; Van der Walt and Midgley Principles of Delict 226; Burchell Principles of Delict 84; Visser "Compensation for Pecuniary Loss" 1122. 
the commission of the alleged delict. The actor must understand the difference between what is right and wrong and thereafter act in accordance with such an understanding. ${ }^{84}$ An investigation into subjective factors relating to the actor, such as his or her level of knowledge, state of mind, level of maturity, experience and general overall mental development at the time of the commission of the alleged delict are considered. ${ }^{85}$ Under certain circumstances children, ${ }^{86}$ mentally impaired, emotionally distressed, ${ }^{87}$ intoxicated ${ }^{88}$ and provoked ${ }^{89}$ persons may lack accountability. ${ }^{90}$

According to sections 7 and 11 of the Child Justice Act, ${ }^{91}$ a child from birth to nine years of age is culpae incapax and cannot be held accountable. ${ }^{92} \mathrm{~A}$ child from twelve to fourteen years of age can be held accountable unless the contrary is proven, and a child between fourteen and eighteen years of age is presumed to be culpae capax (accountable) unless the contrary is proven. In terms of common law, a child below the age of seven is culpae incapax and a child between seven and fourteen years of age is culpae capax. ${ }^{93} \mathrm{~A}$ child between fourteen and eighteen years of age is culpae capax depending on the circumstances of the case. ${ }^{94}$ Jansen and

Weber v Santam Versekeringsmaatskappy Bpk 19831 SA 381 (A) 389; Neethling and Potgieter Law of Delict 131; Loubser and Midgley Law of Delict 139; Burchell Principles of Delict 83; Van der Walt and Midgley Principles of Delict 226. Weber v Santam Versekeringsmaatskappy Bpk 19831 SA 381 (A) 390; Van der Walt and Midgley Principles of Delict 226-227; cf Burchell Principles of Delict 83. Boberg Law of Delict 659.

87 See S v Campher 19871 SA 940 (A); S v Laubscher 19981 SA 163 (A); Neethling and Potgieter Law of Delict 159; Loubser and Midgley Law of Delict 142.

See $S v$ Chretien 19811 SA 1097 (A), where the accused was found not guilty of murder and assault as a result of being in such a state of intoxication that it rendered him unaccountable and lacking fault in the form of intention. Also see Neethling and Potgieter Law of Delict 159; Loubser and Midgley Law of Delict 143; Van der Walt and Midgley Principles of Delict 227. If a person takes an intoxicating substance before he or she becomes intoxicated, thereafter committing a delict, he or she may still be held liable as a result of his or her prior act while he or she was still accountable. Neethling and Potgieter Law of Delict 159; Loubser and Midgley Law of Delict 143144.

Neethling and Potgieter Law of Delict 158-159; Loubser and Midgley Law of Delict 140; Visser "Compensation for Pecuniary Loss" 1122-1123.

$91 \quad$ Child Justice Act 75 of 2008.

92 Section 4 of the Child Justice Amendment Bill of 2019 is still to become operational, but it states that a child under twelve years of age does not have criminal capacity. See Weber v Santam Versekeringsmaatskappy Bpk 19831 SA 381 (A) and Eskom Holdings Ltd $v$ Hendricks 20055 SA 503 (SCA), where the children lacked accountability on the basis that the children were between seven and fourteen years of age and had not acted in accordance with an appreciation of the difference between what was right and what was wrong. Delict 158; Visser "Compensation for Pecuniary Loss"1123; Loubser and Midgley 
Neethling ${ }^{95}$ submit that the Child Justice Act applies to the accountability of children with regard to crimes. The common law position still applies to delictual liability. ${ }^{96}$

It is settled that the "reasonable person" test applies to children who may be held accountable. ${ }^{97}$ Previously our courts used to follow the "reasonable child" test, which took into account the youthfulness of the child wrongdoer, but the approach took a turn in Jones $v$ Santam Bpk, ${ }^{98}$ when the court stated that in all cases, the objective "reasonable person" test must first be applied. Thereafter it must be determined whether the child can be held responsible for his or her conduct; that is, whether the child can be held accountable, taking into account subjective factors relating to the child. ${ }^{99}$ In Roxa $v$ Mtshayi ${ }^{100}$ the court stated that first it must be ascertained whether the child is accountable, taking subjective factors into account and thereafter determine negligence. Therefore, under the concept of accountability the particular child's subjective age, level of maturity and general mental development etcetera at the time of the alleged delict are taken into consideration and thereafter tested against the objective standard of the reasonable person. ${ }^{101}$ The harshness of applying the reasonable person standard to a child is somewhat alleviated by the rules of accountability. This approach was endorsed in Weber $v$ Santam Versekeringsmaatskappy Bpk $^{102}$ and in Eskom Holdings Ltd $v$ Hendricks. ${ }^{103}$ The standard of the reasonable person that is applied to children in South Africa has been criticised. ${ }^{104}$ Neethling and Potgieter ${ }^{105}$ point out that a noteworthy criticism is that the reasonable child test is a more suitable standard for a child

Law of Delict 141-142 discussion of Weber and Eskom Holdings Ltd; Van der Walt and Midgley Principles of Delict 227. Jansen and Neethling 2017 THRHR 474.

See Loubser and Midgley Law of Delict 140-142; Van der Walt and Midgley Principles of Delict 227, who refer to the common law position with regard to the delictual liability of children. Also see Jansen and Neethling 2017 THRHR 474-482. See in general Neethling and Potgieter Law of Delict 171-173; Loubser and Midgley Law of Delict 135-136 and their discussion of Haffajee $v$ South African Railways and Harbours 19813 SA 1062 (W); Van der Walt and Midgley Principles of Delict 273274; Burchell Principles of Delict 90-91. Jones v Santam Bpk 19652 SA 542 (A) 551-552.

The decision in Jones $v$ Santam 19652 SA 542 (A) has been criticised for in effect determining negligence before accountability. However, in Roxa v Mtshayi 19753 SA 761 (A) 765-766 accountability was correctly determined before negligence (see Neethling and Potgieter Law of Delict 171-173). Roxa $v$ Mtshayi 19753 SA 761 (A) 765-766.

See Neethling and Potgieter Law of Delict 171.

Weber v Santam Versekeringsmaatskappy Bpk 19831 SA 381 (A) 400.

Eskom Holdings Ltd v Hendricks 20055 SA 503 (SCA) 511-512.

See Neethling and Potgieter Law of Delict $144 \mathrm{fn} 109$ and the authority cited therein. Neethling and Potgieter Law of Delict 172. 
because even though a child may be accountable, the child's conduct cannot realistically be measured against that of an adult. ${ }^{106}$

In South African law, if a person has a mental impairment or sustains severe emotional distress and cannot distinguish right from wrong or can but is unable to act in accordance with the appreciation of that distinction at the time of the delict, he or she is culpae incapax. The person does not act with fault and cannot be held delictually liable. ${ }^{107}$ The position in South African law, as will be explained further below, is markedly different from that in French and Anglo-American law. ${ }^{108}$

Van der Walt and Midgley ${ }^{109}$ point out that there is a lack of authority on whether subjective physical attributes of the person such as a person's disabilities play a part in determining negligence. However, with reference to common law Van der Walt and Midgley ${ }^{110}$ state that the general approach is to consider the physical disability in adjusting the (base) standard of the reasonable person. The conduct of the person with a physical disability must still be reasonable in the light of his or her knowledge of the disability. ${ }^{111} \mathrm{~A}$ person who is visually impaired and aware of it will be found negligent if he or she drives a car on the street and causes harm to another. ${ }^{112}$

From a cursory reading of textbooks on delict, there is also a lack of authority on how the standard of the reasonable person should be applied to the elderly. It may be assumed, though, that in terms of a common sense approach, the base standard could be adjusted and perhaps lowered when applied to the elderly in view of their age, physical and cognitive abilities. However, along the same lines as the person with a physical disability, the conduct of the elderly person must still be reasonable in the light of his age, physical and cognitive abilities.

106 Also see Loubser and Midgley Law of Delict 173-174 with reference to different outcomes reached (dealing with children) in Eskom Holdings Ltd v Hendricks 2005 5 SA 503 (SCA) and Hafajee $v$ South African Railways and Harbours 19813 SA $1062(\mathrm{~W})$.

Neethling and Potgieter Law of Delict 158; Loubser and Midgley Law of Delict 140143; Van der Walt and Midgley Principles of Delict 227. Also see $S$ v Campher 1987 1 SA 940 (A) with regard to emotional and mental distress; $S v$ Chretien 19811 SA 1097 (A) with regard to severe intoxication. See paras 3.2-3.4 below with regard to French and Anglo-American law. Van der Walt and Midgley Principles of Delict 241.

Van der Walt and Midgley Principles of Delict 241.

$R v$ Verster 19522 SA 231 (A) 234; Van der Walt and Midgley Principles of Delict 241.

112 Van der Walt and Midgley Principles of Delict 241. 
The reasonable person standard in South African law, generally, does not relate to a specific gender ${ }^{113}$ or to a particular physical characteristics of a person. ${ }^{114}$ It is not expected of the person to be exceptionally skilled, developed or too careful, nor is the person underdeveloped, thoughtless or reckless. ${ }^{115}$ The reasonable person test is flexible and adaptable in that the courts adapt the standard depending on the circumstances of each case.

At times the adjudicator may raise the standard in instances where the defendant has expertise in a certain field. ${ }^{116}$ For example, the conduct of a doctor would be tested against the standard of the reasonable doctor and not against the standard of the reasonable person. ${ }^{117}$ The "reasonable expert" test is similar to the reasonable person test, although a reasonable measure of the particular expertise is applied. ${ }^{118}$ The reasonable expert test does not expect the person to have the highest level of skill and expertise but rather the "general level of skill and diligence possessed and exercised at the time by members of the branch of the professional to which the practitioner belongs." 119 The test is based on the acquired necessary knowledge as well as the exercise of the necessary skill, care and diligence. ${ }^{120}$ Besides the application of the standard of the reasonable expert, the court will still look at the surrounding circumstances of the case and then decide what conduct was reasonably to be expected in the

\footnotetext{
113 Neethling and Potgieter Law of Delict 169-170.

114 Weber v Santam Versekeringsmaatskappy Bpk 19831 SA 381 (A) 410-411.

115 See in general Neethling and Potgieter Law of Delict 169-170; Loubser and Midgley Law of Delict 154; Van der Walt and Midgley Principles of Delict 239. Van den Heever JA in Herschel $v$ Mrupe 19543 SA 464 (A) 490 stated that the concept of the "bonus paterfamilias is not that of a timorous faintheart always in trepidation lest he or others suffer some injury; on the contrary, he ventures out into the world, engages in affairs and takes reasonable chances. He takes reasonable precautions to protect his person and property and expects others to do likewise." Also see iMvula Quality Protection v Loureiro 20133 SA 407 (SCA) 416.

116 Scott 2014 De Jure 390.

117 See Van Wyk v Lewis 1924 AD 438 456; Lymbrey $v$ Jefferies 1925 AD 236; Esterhuizen v Administrator, Transvaal 19573 SA 710 (T) 723; Louwrens v Oldwage 20061 All SA 197 (SCA) 207; Medi-Clinic v Vermeulen 20151 SA 241 (SCA) 243 with respect to the reasonable doctor test.

118 See Neethling 2002 SALJ 287; Neethling and Potgieter Law of Delict 173-176; Loubser and Midgley Law of Delict 171; Van der Walt and Midgley Principles of Delict 269-270; Boberg Law of Delict 346.

119 Van Wyk v Lewis 1924 AD 438, 444; Neethling and Potgieter Law of Delict 147; Loubser and Midgley Law of Delict 171-172; Van der Walt and Midgley Principles of Delict 269.

120 Van der Walt and Midgley Principles of Delict 269.
} 
circumstances. ${ }^{121}$ The same standard of competence is required of persons with similar skills, irrespective of their experience. ${ }^{122}$

Where there is a lack of experience, for example in the case of a learner driver who does not have the knowledge or skill of an experienced driver, the lack of experience may not count in his or her favour and he or she may not be excused or treated more leniently because of the lack of experience. ${ }^{123}$ Even though beginners or novices are encouraged to develop and apply their knowledge, skill and experience in their occupation or profession, if their lack of skill and experience poses a danger to others, the standard of the reasonable person may not be lowered. ${ }^{124}$ Where the beginner driver creates an appreciable risk of harm, it is expected of him or her to act with the same level of proficiency as an experienced driver. ${ }^{125}$ However, a novice golfer ${ }^{126}$ or young, inexperienced teacher ${ }^{127}$ will not be expected to display the same level of knowledge and skill as that of the experienced teacher or golfer. It is apparent that the base standard of the reasonable person is applied where the risk of harm is appreciable. In instances where a person undertakes an activity which requires a certain level of skill and knowledge and that person knows or ought to know that he or she lacks the skill or knowledge but still undertakes the activity, the person may be found negligent. ${ }^{128}$

\subsection{The United Kingdom (English law)}

\subsubsection{The tort of negligence}

As already mentioned, ${ }^{129}$ Anglo-American tort law comprises of a system of a number of torts. There is the tort of negligence and numerous intentional torts. For the purpose of this contribution, the tort of negligence is of importance. In the tort of negligence, the standard of care is generally tested objectively against the reasonable person, ${ }^{130}$ also referred to as the ordinary

\footnotetext{
$121 \quad$ Neethling and Potgieter Law of Delict 175; Loubser and Midgley Law of Delict 172.

122 Van der Walt and Midgley Principles of Delict 269.

123 Loubser and Midgley Law of Delict 171.

$124 \quad$ See Van der Walt and Midgley Principles of Delict 271.

125 See Simon's Town Municipality v Dews 19931 SA 191 (A); Loubser and Midgley Law of Delict 171.

126 Clark v Welsh 19763 SA 484 (A) 486; Van der Walt and Midgley Principles of Delict 272.

127 Jacobs v Chairman, Governing Body, Rhodes High School 20111 SA 160 (WCC)

[73, 76]; Van der Walt and Midgley Principles of Delict 272.

128 Loubser and Midgley Law of Delict 171.

129 In para 1 above.

130 Peel and Goudkamp Winfield and Jolowicz on Tort 143; Jones "Negligence" 553.
} 
man or woman on the "Clapham omnibus". ${ }^{131}$ The reasonable person is not exceptionally skilled or inexperienced, ${ }^{132}$ nor is he or she extraordinary careful or extraordinarily vigilant. ${ }^{133}$ Lord Macmillan in Glasgow Corporation $v$ Muir $^{134}$ stated that the standard "eliminates the personal equation and is independent of the idiosyncrasies of the particular person whose conduct is in question."

It is trite law that the standard of care varies with certain types of defendants such as children, persons with disabilities or impairments, or professionals.

In respect of professionals such as doctors, the standard applied is the reasonable, skilled, competent, professional doctor. ${ }^{135}$ In assessing the standard of reasonableness of professionals, unrealistic standards, knowledge or skill must not be expected of them. ${ }^{136}$ Bolam $v$ Friern Hospital'137 (hereinafter referred to as "Bolam") is authority ${ }^{138}$ for the approach applied to professionals, which is the "standard of the ordinary skilled man exercising and professing to have that special skill." In this wellknown case it was held that "a doctor who had acted in accordance with a practice accepted at the time as proper by a responsible body of medical opinion skilled in the particular form of treatment in question was not guilty of negligence merely because there was a body of competent professional opinion which might adopt a different technique."139 Therefore, a professional who acts according to the practice accepted by a responsible body of persons experienced and skilled in that particular profession may not be held negligent. This is commonly referred to as the "Bolam principle". ${ }^{140}$ Furthermore, where there are almost equally compelling professional opinions or where the opinions are divided, the professional will not be held liable. ${ }^{141}$

\footnotetext{
131 Deakin and Adams Markesinis and Deakin's Tort Law 185.

132 Peel and Goudkamp Winfield and Jolowicz on Tort 145, 146.

133 Deakin and Adams Markesinis and Deakin's Tort Law 189-190.

134 Glasgow Corporation v Muir 1943 AC 488.

135 Deakin and Adams Markesinis and Deakin's Tort Law 190.

$136 \quad$ Witting Street on Torts 137-139.

137 Bolam v Friem Hospital 19571 WLR 582586.

138 See Maynard v West Midlands RHA 19841 WLR 634; Sidaway $v$ Bethlem Royal Hospital 1985 AC 871.

139 Bolam v Friem Hospital 19571 WLR 582587.

140 See Deakin and Adams Markesinis and Deakin's Tort Law 189-190; Peel and Goudkamp Winfield and Jolowicz on Tort 157.

141 Deakin and Adams Markesinis and Deakin's Tort Law 190; Peel and Goudkamp Winfield and Jolowicz on Tort 157. In Medi-Clinic Ltd v Vermeulen 20151 SA 241 (SCA) 243-245, the South African Supreme Court of Appeal when faced with two conflicting medical opinions referred with approval to the Bolam principle as well as
} 
In respect of defendants with exceptional skills, the subjective level of skill of the defendant is not taken into account and all that is required is the standard expected of the reasonably skilled person. ${ }^{142}$ If a defendant professes to have a particular acquired skill or experience, however, he or she will be held to a reasonable degree to such skill or expertise. ${ }^{143}$

The standard of the reasonable person may be adjusted depending on the circumstances and risks involved. For example, in Wells $v$ Cooper $^{144}$ the defendant had negligently fitted a door handle himself. The plaintiff was injured when the door handle came loose from the door. The Court of Appeal was faced with the question of which standard of care should be applied in such an instance. The court held that the standard should not be that of the reasonable competent carpenter but that of the reasonably skilled amateur carpenter. ${ }^{145}$ In Philips $v$ William Whitely $L t d^{146}$ a jeweler pierced the plaintiff's ears and it appeared that he took steps to disinfect the pierced ears but an abscess subsequently developed which could have been avoided had it been done by a medical practitioner. The court held that the jeweler took reasonable steps to avoid infection and needed to show only the skill required of a jeweler and not that of a surgeon. ${ }^{147}$ If a defendant is lacking in experience or skill in comparison to the reasonable person, the defendant may still be held liable in spite of his or her incompetence. ${ }^{148}$ The authority for this approach stems from the well-known case, Nettleship $v$ Weston. ${ }^{149}$ In this case the Court of Appeal held that a learner driver who collided with a lamppost causing injury to her instructor was liable based on the (base) standard of the reasonable driver. ${ }^{150}$ Although it may be argued that the conduct of the learner driver was something that could have been

the two English decisions of Bolitho $v$ City Hackney Health Authority 1998 AC 232 243-244 and Roe $v$ Minister of Health 19542 QB 66 252. The court concluded that the hospital was not negligent in failing to ensure that a patient did not develop bed sores in the circumstance which led to his eventually being paralysed and confined to a wheelchair.

142 Peel and Goudkamp Winfield and Jolowicz on Tort 144; Jones "Negligence" 556.

143 Woolridge v Sumner 19632 QB 43; Witting Street on Torts 137-138.

144 Wells v Cooper 19582 QB 265.

145 Deakin and Adams Markesinis and Deakin's Tort Law 185.

146 Philips $v$ William Whitely Ltd 19381 All ER 566.

$147 \quad$ Witting Street on Torts 132.

148 Peel and Goudkamp Winfield and Jolowicz on Tort 143.

149 Nettleship v Weston 19712 QB 691. In Wilsher v Essex Area Health Authority 1987 QB 730, the fact that the defendant was lacking experience in that he was a junior doctor was not taken into account. See Peel and Goudkamp Winfield and Jolowicz on Tort 146-147; Jones "Negligence" 554; Deakin and Adams Markesinis and Deakin's Tort Law 188-189; Witting Street on Torts 135.

150 See Cook v Cook 198668 ALR 353, where the High Court of Australia took into account the inexperience of the learner driver. However, the same approach was not followed in McNeilly v Imbree 2008 HCA 40. 
expected, the court was influenced inter alia by the fact that she had previously been convicted of driving without due care, and had insurance..$^{151}$

In respect of a child defendant, the test is varied to that of the reasonable child of the same age. ${ }^{152}$ It has not been settled in English tort law whether the child's subjective maturity, mental ability or experience should be considered. ${ }^{153}$ However, in exceptional circumstances where a child partakes in activities normally undertaken by an adult, the reasonable person test will apply. ${ }^{154}$ In general, a very young child, for example, under the age of three years old cannot be held liable. ${ }^{155}$

Moran ${ }^{156}$ refers to a number of examples to illustrate under what circumstances child defendants are held liable in terms of Common Law. For example, in McHale $v$ Watson ${ }^{157}$ a twelve-year-old boy threw a metal rod which struck a nine-year-old girl's right eye, rendering her blind in that eye. The standard applied was that of an ordinary child of a similar age. ${ }^{158}$ Moran ${ }^{159}$ explains how content was given to the standard; that is, whether the young boy had behaved reasonably in the circumstances. In respect of foreseeability, it was held that the child did not have knowledge or appreciation of the risk of throwing the rod. ${ }^{160} \mathrm{He}$ did not reasonably foresee that when the rod was thrown it would taper off and strike the girl. ${ }^{161}$ The boy's age limited his ability to foresee harm and also his ability to act prudently. ${ }^{162} \mathrm{He}$ was found not culpable because his "capacity for foresight or prudence" was "characteristic of humanity at his stage of development and in that sense normal." ${ }^{163}$ Moran highlights that the court found the boy's conduct normal, natural, and not an idiosyncrasy. ${ }^{164}$ Kitko $\mathrm{J}^{165}$ concluded,

$151 \quad$ Nettleship v Weston 19712 QB 691 699. See Deakin and Adams Markesinis and Deakin's Tort Law 189.

152 See Mullin v Richards 19981 WLR 1304 1308-1309, where the standard applied was that of "an ordinarily prudent and reasonable fifteen-year old schoolgirl in the defendant's situation"; Blake v Galloway 20041 WLR 284; Orchard v Lee 2009 PIQR P16; Peel and Goudkamp Winfield and Jolowicz on Tort 146; Jones "Negligence" 562-563; Deakin and Adams Markesinis and Deakin's Tort Law 187-188.

$153 \quad$ Witting Street on Torts 135.

154 Peel and Goudkamp Winfield and Jolowicz on Tort 148.

155 Witting Street on Torts 135.

156 Moran Rethinking the Reasonable Person 60-83.

157 McHale $v$ Watson 1966115 CLR 199 (Aust HC).

158 Moran Rethinking the Reasonable Person 63, 215.

159 Moran Rethinking the Reasonable Person 64.

160 McHale $v$ Watson 1966115 CLR 199 (Aust HC) 214-215.

161 McHale $v$ Watson 1966115 CLR 199 (Aust HC) 215-216.

162 McHale $v$ Watson 1966115 CLR 199 (Aust HC) 215.

163 McHale $v$ Watson 1966115 CLR 199 (Aust HC) 213.

164 Moran Rethinking the Reasonable Person 77.

165 McHale $v$ Watson 1966115 CLR 199 (Aust HC) 216. 
"that boys of twelve may behave as boys of twelve and that, sometimes, is a risk indeed." Moran ${ }^{166}$ submits that the majority of judges had empathy for the boy. They referred to the nostalgia of their childhood and they could not find liability for "boyish imprudence". Moran explains that after surveying cases $^{167}$ involving children, almost "all of the child defendants are boys". ${ }^{168}$ Moran ${ }^{169}$ refers to Michaud $v$ Dupuis, ${ }^{170}$ where the court found negligent an eleven-year-old boy who threw a stone at a four-year-old girl rendering her blind in an eye. The court ${ }^{171}$ found his conduct "reckless ... with complete disregard for the safety of other people." Moran ${ }^{172}$ points out that there was no mutual play, there was a larger age difference between them and the boy's conduct was close to the intentional infliction of harm. In Pollock $v$ Lipkowitz $^{173}$ a thirteen-year-old boy was found liable for his "senseless act of folly"174 when he threw nitric acid at an eleven-year-old girl. Thus the latter two cases illustrate abnormal behaviour. ${ }^{175}$ In Mullin v Richards, ${ }^{176}$ where two fifteen-year-old schoolgirls were playing sword-fighting with rulers, the ruler snapped and a fragment of the plastic struck Mullin's eye, rendering her blind in that eye. The appeal court held that both the girls' conduct was not excessively or inappropriately violent. Their conduct was commonplace in school and neither of them had foreseen the risk of harm. ${ }^{177}$ Butler-Sloss LJ concluded that "girls of 15 playing together may play as somewhat irresponsible girls of 15."178 Moran ${ }^{179}$ submits that the objective standard of reasonableness relates to the ordinariness, normalcy or commonness of sword-fighting and the lack of foreseeability of harm.

Moran ${ }^{180}$ interestingly refers to the application of the doctrine of allurement. According to this doctrine, children are often naturally tempted and attracted to play with dangerous things but are unaware of the reality of the danger.

\footnotetext{
166 Moran Rethinking the Reasonable Person 79-82.

167 At the time of writing the book.

168 Moran Rethinking the Reasonable Person 86.

169 Moran Rethinking the Reasonable Person 86.

$170 \quad$ Michaud v Dupuis 197720 NBR 2d 305 (QB).

171 Michaud v Dupuis 197720 NBR 2d 305 (QB) 308.

172 Moran Rethinking the Reasonable Person 86.

173 Pollock v Lipkowitz 197017 DLR 3d 766 (Man QB). See Moran Rethinking the Reasonable Person 86.

$174 \quad$ Pollock v Lipkowitz 197017 DLR 3d 766 (Man QB) 768.

175 Moran Rethinking the Reasonable Person 86-87.

176 Mullin v Richards 19981 All ER 920 (CA). See Moran Rethinking the Reasonable Person 88-89.

177 Mullin v Richards 19981 All ER 920 (CA) 927.

178 Mullin $v$ Richards 19981 All ER 920 (CA) 928.Also see Blake v Galloway 20041 WLR 284, where the court found that horseplay between two fifteen-year old children did not amount to negligence.

179 Moran Rethinking the Reasonable Person 89-90, 94, 129, 131.

180 Moran Rethinking the Reasonable Person 97-98, 114.
} 
They are generally not held liable because this behaviour is considered natural. ${ }^{181}$

In situations where a person suffers some kind of physical disability ${ }^{182}$ such as a heart attack, ${ }^{183}$ loss of consciousness as a result of hypoglycaemia ${ }^{184}$ or a sudden blackout not caused by his or her own fault, the person will not be held liable. In English law it is acknowledged that the reasonable person may suffer a disabling condition which suddenly manifests itself and of which he or she is not aware (or should not reasonably have been reasonably aware of). Under the circumstances, the reasonable person with the sudden disabling condition may have acted as the defendant did. ${ }^{185}$ English law does not differentiate between conduct and fault as in South African law, where both conduct and fault under such circumstances would be absent. If the defendant through fault on his part forgets to take his medication, thereby leading to a blackout, the principle of "prior fault" applies and the defendant may be held liable. ${ }^{186}$

A mentally impaired person can generally be held liable and the standard of the reasonable person will be applied unless the person "cannot understand the nature and consequence of his act." ${ }^{187}$ The decision would depend on

181 Moran Rethinking the Reasonable Person 104, 107, 126-128 refers to Gough v National Coal Board 19532 All ER 1283 (CA) 1293, where it was stated the boy was "extremely likely to succumb to the temptation" and boys have been behaving in such a manner since "time immemorial"; Cooke v Midland Great Western Railway of Ireland 1909 AC 229 (HL) 237, where unguarded vehicles and machines were considered "calculated to attract or allure"; Lengyel v Manitoba Power Commission 195712 DLR 2d 126 (Man CA) 133, where the court held that the device was "calculated to attract small boys, to arouse their curiosity"; Coley v CPR 190629 (Que SC) 285, where it was held that a turntable was an allurement to children. In this case a nine-year-old girl was playing on a turntable and was seriously injured resulting in the amputation of her foot. See further cases referred to by Moran Rethinking the Reasonable Person 104-107.

182 Or has a condition.

183 See Roberts $v$ Ramsbottom 19801 WLR 823, where the defendant who was unaware that he had suffered a stroke resulting in an accident but admitted to feeling dizzy before driving, was found negligent. The court held that the plaintiff continued to drive when he should have been aware that he was unfit and would have escaped liability only if his actions had been entirely beyond his control. Witting Street on Torts 135-136.

184 In Mansfield $v$ Weetabix 1998 1 WLR 12631268 Leggat LJ held that the standard of care applicable to the driver who suffered from hypoglycaemia of which he was unaware was judged according to "that which is to be expected of a reasonably competent driver unaware that he is or may be suffering" from such a condition. The Appeal Court found the driver not liable. See Jones "Negligence" 561; Witting Street on Torts 136.

185 Peel and Goudkamp Winfield and Jolowicz on Tort 148. See Ahmed 2019 PELJ 13.

186 Peel and Goudkamp Winfield and Jolowicz on Tort 149.

187 Peel and Goudkamp Winfield and Jolowicz on Tort 778 with reference to Hanbury $v$ Hanbury 18928 TLR 559569. 
whether the defendant had the "requisite state of mind for liability in the particular tort with which he is charged."188 For example, in Morris $v$ Marsden ${ }^{189}$ the mentally impaired defendant attacked the manager of the hotel he was staying at. It transpired that the defendant was aware of the nature and extent of his conduct but not aware that what he was doing was indeed wrong. It was held that because he was aware of the nature and extent of his conduct, he was liable for the intentional tort of battery. His obliviousness of the fact that what he was doing was wrong was considered immaterial. ${ }^{190}$ Stable $\mathrm{J}^{191}$ held that if a person acts without intention and "carelessness", causing grievous injury, thus being without fault and in a complete state of automatism, then he cannot be held liable. ${ }^{192}$

\subsection{The United States of America (American law)}

\subsubsection{Tort of negligence}

Once it has been established that a duty of reasonable care is owed, the conduct of the parties is tested against the standard of a reasonable person under the circumstances. ${ }^{193}$ Sometimes the standard must be adjusted, for example to that of the reasonable professional, and the adjudicator determines the standard that should be applied in the particular circumstances of the case. ${ }^{194}$ The standard of the reasonable person is predominantly objective in that it applies generally to cases testing the parties' conduct against the hypothetical, model reasonable person. It is an external standard based on "what society demands generally of its members rather than upon the actor's personal morality or individual sense

\footnotetext{
$188 \quad$ Peel and Goudkamp Winfield and Jolowicz on Tort 778.

189 Morris v Marsden 19521 All ER 925.

190 Peel and Goudkamp Winfield and Jolowicz on Tort 778; McBride and Bagshaw Tort Law 699.

$191 \quad$ Morris v Marsden 19521 All ER 925, 927.

192 See Ahmed 2019 PELJ 11.

193 See Lugtu v Cal Highway Patrol 26 Cal 4th 703, 110 Cal Rptr 2d 528, 28 P 3d 249 (2011); Gossett v Jackson 249 Va 549, 457 SE 2d 97 (1995); American Law Institute Restatement Second of Torts 1965 § 282-283 (1965); American Law Institute Restatement Third of Torts 2010 §§ 7, 16(2); Dobbs, Hayden and Bublick Hornbook on Torts 214. Different volumes of the Restatement of Torts will be referred to in this contribution as they are influential in American law. These volumes consist of black letter law applied throughout the different states in the United States of America as well as case law restating current existing common law, see Zweigert and Kötz Introduction to Comparative Law 252. See Ahmed 2019 PELJ fn 102.

194 American Law Institute Restatement Third of Torts 2010 § 10(1).
} 
of right and wrong." 195 The reasonable person has reasonable prudence ${ }^{196}$ as well as common knowledge, ${ }^{197}$ is cautious, ${ }^{198}$ and possesses normal perception and memory. ${ }^{199}$ The subjective part of the reasonable person standard relates to "additional intelligence, skill, or knowledge actually possessed by the individual"200 coupled with his "physical attributes", although they are still tested objectively. ${ }^{201}$

The Restatement Third of Torts ${ }^{202}$ refers to superior skills or knowledge as circumstances to be taken into account in determining whether the actor acted reasonably. For example, a race car driver who has superior driving abilities would be more skilled at avoiding an accident in an emergency than an ordinary driver. The race car driver may be held negligent for failing to use his superior skill in avoiding an accident. ${ }^{203}$

Professionals are expected to exercise reasonable care and to possess a minimum standard of knowledge and ability. If the professional professes further specialised knowledge or skills, the standard is adjusted to the specialised skill and knowledge held to the accepted practice, customary

195 Keeton et al Prosser and Keeton on the Law of Torts 169. See McNeely $v$ M \& M Supermarkets Inc 1980154 Ga App 675, 269 SE 2d 483; Stewart v Jefferson Plywood Co 1970255 Or 603, 469 P 2d 783.

196 See Trentacoast v Brussel 198082 NJ 214, 412 A 2d 436; Swenson Trucking \& Excavating Inc v Truckweld Equipment Co Alaska 1980604 P 2d 1113; Keeton et al Prosser and Keeton on the Law of Torts 174 (referring to the reasonable prudent person).

197 Compared with common knowledge in the community at the time of the tort.

198 See Massey v Scripter 1977401 Mich 385, 258 NW 2d 44; St Mary's Hosp Inc v Bynum, Ark 1978573 SW 2d 914; Keeton et al Prosser and Keeton on the Law of Torts 174 (referring to the reasonably careful person).

199 Dobbs, Hayden and Bublick Hornbook on Torts 222, 229. See Restatement Second of Torts 1965 289-290, which states that an ordinary person has knowledge that matches will burn, alcohol induces intoxication, gravity makes weight fall from a high place, and a person can get electrocuted when coming into contact with a power line. American Law Institute Restatement Third of Torts 2010 § 12. For example, a reasonable person is not expected to know that fumes from gasoline are heavier than air (see Blakes $v$ Blakes 517 So 2d 444 (La Ct App 1987)). Also see the discussion by Keeton et al Prosser and Keeton on the Law of Torts 182-185 with regard to the difficulty with the question of how much knowledge the defendant is required to possess.

200 See American Law Institute Restatement Second of Torts 1965 §§ 289, $290 \mathrm{cmt}$ f, $299 \mathrm{cmt} f$.

201 Dobbs, Hayden and Bublick Hornbook on Torts 222.

202 American Law Institute Restatement Third of Torts 2010 § 12. See Sinai v Polinger Co 498 A 2d 520 (DC 1985); Dobbs, Hayden and Bublick Hornbook on Torts 230231. See fn. 195 above regarding the different volumes of the Restatement of Torts referred to in this contribution.

203 See American Law Institute Restatement Third of Torts $2010 \S 12$; Green and Cardi "Basic Questions of Tort Law" 484. 
and usual standard of the relevant professional, such as a doctor, dentist, accountant etcetera. ${ }^{204}$

A person with a disability is judged according to the standard of the reasonable person with such a disability. ${ }^{205}$ The Restatement Third of Torts $^{206}$ with reference to conduct of persons with physical disability states that the standard of negligence is that of a "reasonably careful person with the same disability". This standard is usually applied to persons who are blind or deaf or where there is a loss of a motor function. ${ }^{207}$ If a person is below average in "judgment, knowledge, or skills" such as a learner driver, he or she is still judged according to the (base) standard of the reasonable person. 208

A person who is "reasonably unaware" of his or her physical limitation, impairment or disability, as when a person unaware of her heart condition suffers a heart attack, may not be held liable, as the heart attack was not foreseeable. ${ }^{209}$ Even though conduct is present, negligence is absent. ${ }^{210}$ The same principles will apply with other types of conditions, as when a person sustains an epileptic fit, sustains a stroke, or faints. ${ }^{211}$ In instances where a person is aware of their physical impairment, pre-existing condition or disability or can reasonably foresee that they are prone to such a condition, impairment or disability, the person may be held negligent for not controlling the condition. ${ }^{212}$

204 See the discussion by Keeton et al Prosser and Keeton on the Law of Torts 185-193 as well as the authority referred to.

205 See Fink v City of New York 206 Misc 79, 132 NYS 2d 172 (Sup Ct 1954); American Law Institute Restatement Second of Torts 1965 § 283C; Dobbs, Hayden and Bublick Hornbook on Torts 223; cases referred to Keeton et al Prosser and Keeton on the Law of Torts 176 fn. 23 in respect of people with disabilities, who are blind and deaf.

206 American Law Institute Restatement Third of Torts 2010 § 11(a).

207 Epstein and Sharkey Cases and Materials on Torts 158.

208 American Law Institute Restatement Third of Torts $2010 \S 10 \mathrm{cmt} b$; Epstein and Sharkey Cases and Materials on Torts 147-148.

209 See Ahmed 2019 PELJ 20-21.

210 See Baker v Joyal 4 AD 3d 596, 771 NYS 2d 269 (2004); Hancock-Underwood v Knight 670 SE 2d 720 (Va 2009); American Law Institute Restatement Third of Torts 2010 § 11(b); Dobbs, Hayden and Bublick Hornbook on Torts 224; Ahmed 2019 PELJ fn. 147.

211 See Ahmed 2019 PELJ 2019 20-21, fn. 148; Moore v Preenell 197738 Md App 243, 379 A 2d 1246 as well as Frechette $v$ Welch (1st Cir 1980) 621 F 2d 11; Keeton et al Prosser and Keeton on the Law of Torts 162.

212 See Ahmed 2019 PELJ fn. 149; Goodrich v Blair 132 Ariz 459, 646 P 2d 890 (1982); Lutzkovitz v Murray 339 A 2d 64, 93 ALR 3d 321 (Del 1975); Howle v PYA/Monarch Inc 288 SC 586, 344 SE 2d 157 (1986); Dobbs, Hayden and Bublick Hornbook on Torts 225 fn157-159. 
Generally, children under the age of five are deemed incapable of being negligent. ${ }^{213}$ In a few states, children under seven years of age may not be held liable in tort and children from seven to fourteen years of age are presumed incapable of negligence which may be rebutted. ${ }^{214}$ The conduct of a minor is not judged according to the standard of the reasonable person or the reasonable child of the same age but with the care of a reasonable person "of his age, intelligence, and experience in similar circumstances", (a more subjective standard). ${ }^{215}$ Liability in tort will depend on whether in the light of the child's age, experience and intelligence he or she acted reasonably. ${ }^{216}$ The age of the child, maturity, knowledge, prior experience, whether he or she can understand the consequences of his or her actions (accountability), as well as other surrounding circumstances are taken into account. ${ }^{217} \mathrm{~A}$ child with a mental impairment or incapacity is not expected to act with the care of a child without such an impairment or incapacity. ${ }^{218}$ Similarly, a child with the experience and intelligence equivalent to that of an adult will be expected to act like a reasonable person. ${ }^{219} \mathrm{~A}$ child's conduct may be judged according to the standard of the reasonable person when a child undertakes a dangerous activity usually undertaken by adults. ${ }^{220}$ For example, the courts have applied the reasonable person test

213 See Mastland Inc v Evans Furniture Inc 498 NW 2d 682 (lowa 1993); Price $v$ Kitsap Transit 125 Wash 2d 456, 886 P 2d 556 (1994); American Law Institute Restatement Third of Torts $2010 \S 10$ (b); Dobbs, Hayden and Bublick Hornbook on Torts 233; Epstein and Sharkey Cases and Materials on Torts 150.

214 Georgia has by a statute exempted children under thirteen years of age from liability in tort. See Horton v Hinley 261 Ga 863, 413 SE 2d 199 (1992); Savage Indus v Duke 598 So 2d 856 (Ala 1992); Queen Ins v Hammond 374 Mich 655, 132 NW 2d 792 (1965); Steele v Holiday Inns Inc 626 So 2d 593 (Miss 1993); Dobbs, Hayden and Bublick Hornbook on Torts 233; authority referred to by Keeton et al Prosser and Keeton on the Law of Torts 179 fn. 58.

215 See First Nat'l Bank of Ariz v Dupree 136 Ariz 296, 665 P 2d 1018 (Ct App 1983); Lehmuth v Long Beach Unified Sch Dist 53 Cal 2d 544, 348 P 2d 887, 2 Cal Rptr 279 (1960); American Law Institute Restatement Second of Torts 1965 § 283A; Restatement Third of Torts 2010 §§ 8(2), 10(a); Dobbs, Hayden and Bublick Hornbook on Torts 233 fn. 224; cases referred to by Keeton et al Prosser and Keeton on the Law of Torts 179 fn. 47.

216 See cases cited by Dobbs, Hayden and Bublick Hornbook on Torts 233 fn 227-280.

217 See Hudson v Old Guard Ins 3 A 3d 246 (Del 2010); Dobbs, Hayden and Bublick Hornbook on Torts 233 fn 236.

218 See Lafayette Par Sch Bd v Cormier ex rel Cormier 901 So 2d 1197 (La Ct App 2005); Dobbs, Hayden and Bublick Hornbook on Torts 234.

219 Dorais v Paquin $113 \mathrm{NH}$ 187, 304 A 2d 369 (1973); Dobbs, Hayden and Bublick Hornbook on Torts 234.

220 See American Law Institute Restatement Second of Torts 1965 § 283(A); American Law Institute Restatement Third of Torts 2010 § 10(c); Dobbs, Hayden and Bublick Hornbook on Torts 236; Epstein and Sharkey Cases and Materials on Torts 150151. 
to children operating a motorised vehicle, ${ }^{221}$ tractor, ${ }^{222}$ boat, ${ }^{223}$ and a snowmobile. ${ }^{224}$ The reasonable person standard, however, does not apply to minors who were involved in hunting accidents where guns were involved ${ }^{225}$ or where minors ride bicycles. ${ }^{226}$

If an elderly driver is not able to respond to accidents as a result of a decline in his or her mental or physical abilities then he or she should not be driving as he or she poses a risk to others. ${ }^{227}$ The Restatement Third of Torts ${ }^{228}$ provides a rule that a child under the age of five cannot be held to be contributorily negligent. This rule has also been applied to an institutionalised elderly person. ${ }^{229}$

A mental impairment, incapacity or disability will generally not exonerate a person from liability in tort. ${ }^{230}$ American law developed in this way and an insane person or a person with a mental impairment will still be judged according to the reasonable person standard. ${ }^{231}$ Even though this has been widely criticised, the standard of care applied to a mentally impaired person

221 See Adams $v$ Lopez $407 \mathrm{P} 2 \mathrm{~d} 50$ (NM 1965) in respect of a motorised scooter; Pritchard v Veterans Cab Co 63 Cal 2d 727, 408 P 2d 360, 47 Cal Rptr 904 (1965); other cases referred to by Dobbs, Hayden and Bublick Hornbook on Torts $236 \mathrm{fn}$ 251; Keeton et al Prosser and Keeton on the Law of Torts 179. See Jackson v McCuiston 448 SW 2d 33 (Ark 1969); Goodfellow v Coggburn 98 Idaho 202, 203-204, 560 P 2d 873 (1977).

223 Dellwo v Pearson 259 Minn 452, 107 NW 2d 859, 97 ALR 2d 866 (1961).

224 See Robinson v Lindsay 92 Wash 2d 410, 598 P 2d 392 (1979); Dobbs, Hayden and Bublick Hornbook on Torts 236; Keeton et al Prosser and Keeton on the Law of Torts 179.

225 See Purtle $v$ Shelton 474 SW 2d 123 (Ark 1971), where the reasonable person standard was not applied, the minors age (a seventeen-year-old child) was considered.

226 American Law Institute Restatement Third of Torts $2005 \S 8 \mathrm{cmt}$; Epstein and Sharkey Cases and Materials on Torts 119.

227 Roberts v Ring 173 NW 437, 438 (Minn 1919); American Law Institute Restatement Third of Torts $2005 \S 9 \mathrm{cmt}$ c; Epstein and Sharkey Cases and Materials on Torts 151.

228 American Law Institute Restatement Third of Torts $2000 \S 10 \mathrm{cmt}$ e. See Dobbs, Hayden and Bublick Hornbook on Torts 392.

229 See Fields v Senior Citizens Ctr Inc 528 So 2d 573, 581 (La Ct App 1988); Dobbs, Hayden and Bublick Hornbook on Torts 392.

230 See McGuire $v$ Almy 8 NE 2d 760 (Mass 1936); Polmatier v Russ 537 A 2d 468 (Conn 1988); Williams v Kearby 775 P 2d 670 (Kan App 1989); American Law Institute Restatement Second of Torts 1979 § 895J; American Law Institute Restatement Third of Torts 2010 § 11(c).

231 See Ahmed 2019 PELJ 21; Keeton et al Prosser and Keeton on the Law of Torts 177 fn. 32 and the cases cited therein; Epstein and Sharkey Cases and Materials on Torts 156. 
or insane person remains that of the reasonable person and not that of the reasonable person affected with a mental impairment. ${ }^{232}$

Certain statutes may in a sense lower the standard of reasonable care. For example, motor vehicles responding to an emergency such as police motor vehicles, fire engines and ambulances etcetera may according to certain legislation disobey usual traffic rules but must still either drive with reasonable care ${ }^{233}$ or not recklessly in the circumstances. ${ }^{234}$

\subsection{France (French law)}

3.4.1 Articles 1382 to 1383 of the French Civil Code of 1804 (hereinafter referred to as the "CC")235 relating to liability for one's own personal conduct where fault is required

The terms "imputability", "discernment" (discernement), or "culpability" in French law are used interchangeably and are somewhat similar to the concept "capacity" in Anglo-American law and "accountability" in South African law. "Imputability" refers to an element of blameworthiness and whether the defendant was aware that his or her conduct was wrongful or could lead to harmful consequences. ${ }^{236}$ In French law the requirement of "imputability" for delictual liability has been dispensed with. This has affected mainly minors and mentally impaired persons. ${ }^{237}$

Previously mentally impaired persons could not be held liable on the ground that the person lacked "imputability". This changed, however, with the

See Torres $v$ City of Los Angeles 58 Cal 2d 35, 372 P 2d 906, 22 Cal Rptr 866 (1962); Frazier v Common Wealth 845 A 2d 253, 260 (Pa Commw Ct 2004); Dobbs, Hayden and Bublick Hornbook on Torts 221 fn. 134.

234 See Robins v City of Wichita 285 Kan 455, 172 P 3d 1187 (2007); Lenard v Dilley 805 So 2d 175 (La 2002); Dobbs, Hayden and Bublick Hornbook on Torts $221 \mathrm{fn}$ 135.

235 The French law of delict is regulated by the French Civil Code of 1804 (the "CC"), in particular Arts 1382-1386.

236 Van Gerven, Lever and Larouche Tort Law 332, 354.

237 Van Gerven, Lever and Larouche Tort Law 332-333.
} 
decision in Buguel $v$ Morin. ${ }^{238}$ Following this decision, Article 489-2239 was subsequently incorporated in the $C C$ (now Article 414-3), ${ }^{240}$ which states that "[h]e who has caused harm to another while under the control of a mental disturbance is nevertheless obligated to provide reparation."241 The intention behind the insertion of this new article was to remove (subjective) "imputability" as a requirement for liability. Mental disturbance is defined in a strict sense for the purposes of this Article and it does not cover brief intervals of lapse of consciousness. ${ }^{242}$ After the implementation of Article 489-2, the Cour de Cassation ${ }^{243}$ in 1976 held that the article applied to all persons with mental impairments whether they were minors or majors. The principles applied in Buguel $v$ Morin are still valid in that they apply in instances where the parent or person responsible for the minor cannot be held liable and where a person who is ill has a duty to take care of himself or herself, which includes taking necessary precautions with regard to his or her condition. ${ }^{244}$

Prior to 1968, children could only be held delictually liable when they had reached the "âge de raison" (age of reason or discernment), typically from seven years onwards. The courts ${ }^{245}$ had to establish in each case whether the child had reached the age of discernment. The "reasonable child" test

238 Cass civ 215 December 1965, D 1966 Jur 397 where a mentally impaired person had just been released form a psychiatric institution. He had not fully recovered but was in a state of "sufficient awareness and free will". It was expected of him to take care of himself but instead he drank heavily for two days. While in the intoxicated state he shot and seriously injured the plaintiff. Criminal proceedings could not be instituted against him due to the mental state he was in when he shot the plaintiff. However, the Cour de Cassation (the highest civil court in France) confirmed that he had committed a faute and that his "mental deficiency which continued to exist, did not deprive him of all awareness and free will." He was held delictually liable. See the discussion of this case in Van Gerven, Lever and Larouche Tort Law 313-314. Law no 68-5 of 3 January 1968 inserted Art 489-2.

Now Art 414-3 by Law no 2007-308 of 5 March 2007.

Légifrance-translations. See Moréteau "Basic Questions of Tort Law" 65.

Where for example a person suffers a heart attack and falls unconscious (Cass civ 24 February 1981 79-11243, Bull civ 1981 II 21, JCP 1981 IV 136). See Van Dam European Tort Law 272; Van Gerven, Lever and Larouche Tort Law 334.

243 Cass civ 120 July 1976 74-10238, Bull civ 1976 I 270 218. See the discussion of this case in Van Gerven, Lever and Larouche Tort Law 336. The Cour de Cassation is the highest civil court in France, see fn 240 above.

244 Van Gerven, Lever and Larouche Tort Law 314.

245 See Cass civ 28 February 1962, Bull civ 1962 II 180, where it was held that an eightyear-old child did not understand that the fire would spread to other buildings and could therefore not be held liable; CA Paris 6 June 1959, D 1959 76, where a sixyear-old child was held liable for running a bicycle against a person who was sitting on a bench; TGI St Etienne 15 May 1974, Gaz Pal 1976 109, where it was held that a fourteen-year-old child was old enough to appreciate the consequences of using an air rifle (Ferreira Fundamental Rights and Private Law in Europe 142-143). Also see Van Dam European Tort Law 272. 
was applied to children, and age was considered as a subjective factor. A similar approach was applied in assessing the conduct of an elderly person, usually over seventy years of age. ${ }^{246}$ In 1984 a number of decisions ${ }^{247}$ dealing with minors were considered culminating in the landmark decision of SAMDA v Molina, ${ }^{248}$ where the Cour de Cassation held that it was not necessary to prove that the minor was able to "appreciate the consequences of his actions" or that he had sufficient discernment to appreciate the consequences of his actions. The Cour de Cassation showed a clear shift in determining faute in an objective manner, dispensing with the requirement of "imputability" in the French law of delict. This shift was aimed at benefitting the plaintiff and protecting his or her rights. ${ }^{249}$ Discernment, however, remains a requirement in criminal law in terms of the French Penal Code (Code Pénal). ${ }^{250}$

Currently, a minor in French law is a child under the age of eighteen years, and in order for a minor to be at fault, it must be shown that he or she did not act like a "bonus pater familias". ${ }^{251}$ This standard is equivalent to the standard of the reasonable person applied in South African and AngloAmerican law in determining negligence. Faute, a concept which encompasses fault as known in South African and Anglo-American law, is now a "social concept" and not a moral concept, ${ }^{252}$ in that it does not refer to morals or culpability and is applied objectively to all persons whether they are minors or have mental impairments and so on. ${ }^{253}$ In French law, parents and other persons who are responsible for minors may be held strictly liable for the conduct of the minors in terms of Article 1384 of the CC. This will be discussed in more detail below. ${ }^{254}$

See Galand-Carval "Liability for Damage Caused by Others" 92; Van Dam European Tort Law 270; Van Gerven, Lever and Larouche Tort Law 336.

247 See Cass Ass plén 9 May 1984 80-93481, Bull crim 1984 164, JCP 1984 II 20255 note Dejean de La Bathie, D 1984525 note Chabas RTDciv 1984509 observations Huet; Moréteau "Basic Questions of Tort Law" 65; Van Gerven, Lever and Larouche Tort Law 336.

Cass civ 212 December 1984 82-12627, Bull civ 1984 II 193. In this case, a sevenyear-old schoolboy violently pushed his classmate. The classmate subsequently struck a bench and sustained a burst spleen which caused a haemorrhage. See the discussion of this case in Van Gerven, Lever and Larouche Tort Law 335-337. Galand-Carval "Liability for Damage Caused by Others" 90.

Van Gerven, Lever and Larouche Tort Law 302.

"Good family father". Galand-Carval "Liability for Damage Caused by Others" 92; Van Dam European Tort Law 270; Van Gerven, Lever and Larouche Tort Law 336.

252 As it does not refer to morals or culpability.

253 See Van Dam European Tort Law 58; Van Gerven, Lever and Larouche Tort Law 280.

254 See para 3.4.2 below. 
French law assesses the defendant's conduct in abstracto as compared to in concreto. That is, is does not consider internal circumstances (subjective factors including inter alia the age or cultural and social characteristics of a person, or the physical, psychological, or other inherent infirmities of a person) but considering external circumstances (the nature of the conduct as well as the time and place where the delict occurred). Certain so-called inferior internal circumstances, such as physical disabilities, or so-called superior factors, such as professional experience or skill, are considered when assessing the degree of caution or diligence required. ${ }^{255}$

Statutory provisions may adjust the standard of the "bonus pater familias". For example, in respect of road accidents where the loi Badinter is applicable, ${ }^{256}$ contributory negligence on the part of a child under sixteen years of age, a person older than seventy years, and a person more than eighty per cent incapacitated can no longer apply as a defence in limiting liability. However, drivers may still be held contributorily negligent. ${ }^{257}$

The standard is adjusted and raised when it comes to professionals like medical practitioners. Sound examples of how the adjusted standard of reasonable conduct is assessed are found in cases dealing with medical practitioners. In private hospitals, medical practitioners including staff at clinics, may generally be held contractually liable. The patient must still prove faute, causation and damage as with delictual liability. The medical practitioner is the debtor in terms of the contractual obligations who must treat the patient with all possible means. ${ }^{258}$ In respect of a contractual obligation, obligation de moyens, the defences that may be raised are contributory fault on the part of the plaintiff or some extraneous cause which cannot be attributed to the conduct of the defendant. ${ }^{259}$ In some instances, an obligation may be to do the best one can do under the circumstances. For example, a medical practitioner has an obligation to use his or her best efforts to cure a patient. 260

Generally, medical practitioners and other staff such as midwives will not be held liable for negligent conduct or have faute if they were acting like reasonable professionals in the course and scope of their functions. Currently, employees may be held liable only if they "wilfully commit a

\footnotetext{
255 Van Gerven, Lever and Larouche Tort Law 353.

256 Law no 85-677 of 5 July 1985, hereinafter referred to as "loi Badinter". This act has regulated traffic accidents in France since 5 July 1985.

Van Gerven, Lever and Larouche Tort Law 314.

See Cass civ 120 May 1936 (Mercier), DP I 88; Brun 2002 Eur Tort Law Yearb 180.

See Van Gerven, Lever and Larouche Tort Law 285.

Van Gerven, Lever and Larouche Tort Law 285-286.
} 
criminal offence" or "act outside the scope of their functions". ${ }^{261}$ For example, in a case ${ }^{262}$ where a patient's intestine was perforated during a colonoscopy, the patient sued the medical practitioner for damages. The medical practitioner argued that the risk was inherent in the technique and that there was no faute on his part. The Cour de Cassation confirmed the decision of the lower court in finding that the perforation resulted from the inept conduct of the medical practitioner in that his conduct strayed from that of the reasonable medical practitioner and was therefore unreasonable. The purpose of the colonoscopy was to examine the intestinal walls, and harm to the intestinal wall was not included. The damages claimed were awarded to the patient. Generally, if there is a risk inherent in the medical procedure, then it is likely that there is no faute on the part of the medical practitioner. In another case ${ }^{263}$ a medical practitioner was not held liable when he performed an operation on the carpal tunnel of the plaintiff's left hand. During the operation he severed the median nerve of the plaintiff's hand. The operation was performed under endoscopy using specific instruments and the procedure itself carries risks because every individual's hand is anatomically different. The Cour de Cassation found that the medical practitioner's conduct was reasonable under the circumstances. The medical practitioner had taken the necessary precautions, had not been careless or negligent, had not committed an error, and there was no faute on his part. In another case, ${ }^{264}$ while operating on a patient's Achilles tendon a surgeon damaged the patient's tibial nerve, even though it was five centimetres away from the tendon. The appeal court held that such a lesion was a risk inherent in such a procedure. The Cour de Cassation agreed and liability was excluded. Moréteau ${ }^{265}$ points out that liability on the part of the medical practitioner may still be found even when the medical procedures carry inherent risks.

Inexperience in French law does not seem to be considered as a mitigating factor or apply in lowering the base standard. For example, in Lignon $v$ Avril266 an amateur volleyball player inadvertently fell down during a game and unintentionally kicked a fellow player, injuring him. The injured player then sued the amateur player. The Cour de Cassation found the amateur

See Cass civ 19 November 2004 01-17908, Bull civ 2004 I 262 219; Moréteau 2007 Eur Tort Law Yearb 276. of this case by Moréteau 2009 Eur Tort Law Yearb 206-208.

263 Cass civ 129 November 2005 03-16308, Bull civ 2005 | 456383.

264 Cass civ 118 September 2008 07-13080, Bull civ 2008 I 206.

265 Moréteau 2009 Eur Tort Law Yearb 207-208.

266 Cass civ 23 July 1991 90-13158, Bull civ 1991 II 210111.
} 
player liable, even though the conduct was involuntary and not wrongful. ${ }^{267}$ The Cour de Cassation found that the inexperienced player could not judge distances and should have warned the other player of his lack of an ability to judge distances. He was found to be negligent in not informing the injured player. ${ }^{268}$ In instances where an inexperienced or drunken driver or pilot raises voluntary assumption of risk as a defence, it is rare that it will apply in exonerating liability but may apply in limiting liability based on contributory fault on the part of the plaintiff. 269

3.4.2 Strict liability for the acts of a person for whom one is responsible in terms of Article 1384 of the CC

The French concept of liability for the act of another is somewhat similar to vicarious liability in other jurisdictions, but in French law fault on the part of the person who committed the delict is not a requirement. Common to both concepts is a differentiation between personal liability and liability for the act of another. ${ }^{270}$ Even though this paragraph does not deal with the application of the standard of the reasonable person in French law, the point here is to give a holistic view of a person's liability for the conduct of a minor or person with a mental impairment.

Stemming from Teffaine ${ }^{271}$ and thereafter the landmark decision referred to as "Blieck", ${ }^{272}$ the Cour de Cassation held that the general provision in Article 1384(1) permitted it to develop further heads of delictual liability. In Blieck a mentally impaired boy was placed in an institution. ${ }^{273}$ He was entrusted to do some unsupervised work outside the centre during the day. One day while working outside the centre, he set fire to the plaintiff's wood. The damages could not be recovered from the boy. The plaintiff claimed from the institution and the Cour de Cassation held that the institution could be held strictly liable in terms of Article 1384(1) as the institution had control and supervision of a permanent nature over the boy. Since this decision a number of institutions have been held liable for acts of persons over which

\footnotetext{
267 See Ahmed 2019 PELJ 23-24.

268 Van Gerven, Lever and Larouche Tort Law 339.

269 See Van Gerven, Lever and Larouche Tort Law 734.

270 Galand-Carval "Liability for Damage Caused by Others" 85.

271 Cass civ 18 June 1896, S 1897117 note Esmein, D 18971 4333, note Saleilles.

272 Cass Ass plén 29 March 1991 89-15231, Bull Ass plén 19911 1, D 1991 Jur 324 note Larroumet, JCP 1991 II 21673, conclusions Dontenwille note Ghestin, Gaz Pal 1991 Jur 513 note Chabas. See Van Dam European Tort Law 68-69; Viney "Tort Liability" 253; Galand-Carval "Liability for Damage Caused by Others" 86 fn 4.

273 Employment Help Centre.
} 
they had permanent or temporary control. ${ }^{274}$ The justification for the liability of the public institution is based on the premise that the public institution takes a "special risk" in establishing itself as such an institution and providing such a service, according to the "risk theory". ${ }^{275}$ The justification for the liability of the acts of the person for whom one is responsible is based on the risk theory. For example, institutions such as medical and rehabilitation institutions, social services, educational institutions and sports clubs take a "special risk" in running such institutions and providing such services. Sports clubs organise, control and direct their members' activities. Parents who have children living with them have power and control over their children while raising them. Parents and most institutions, therefore, have insurance for such potential liability. Therefore, Article 1384(1) allows a plaintiff to claim compensation from the person who cares for, supervises, or has control over the person who caused the damage. ${ }^{276}$ Article 1384(1) may be applied where one is supervising an adult of unsound mind. Liability may be found if the harmful conduct was committed when the defendant had the power to "organize, direct and control the wrongdoer's way of life". ${ }^{277}$ In a case, ${ }^{278}$ an adult who had a mental impairment and was living with his father attended a specialised institution during the day. On one particular day he set fire to a building while on his way home from the institution. The plaintiff sued the institution as well as the father who was his administrateur legal (legal guardian). The Cour de Cassation held that the claim against the institution failed because at the time of the delict he was not under the supervision of the institution. The claim against the father also failed because the child was not a minor.

Article 1384 of the CC provides inter alia for the strict liability of parents for the acts of their children who are still living with them. ${ }^{279}$ In France parents take out insurance which covers damage caused by children for whom they are responsible when they take out home insurance or insurance over rental

274 Such as medical and rehabilitation institutions, social services, educational institutions and sports clubs for harm caused by club players. See Cass crim 26 March 1997 95-83957, Bull crim 1997124 414, JCP 1997 II 22868 and authority cited by Viney "Tort Liability" 253 fn 44-46; Van Dam European Tort Law 69; GalandCarval "Liability for Damage Caused by Others" 86 fn. 5; Van Gerven, Lever and Larouche Tort Law 520-521; Moréteau 2007 Eur Tort Law Yearb 278.

275 Galand-Carval "Liability for Damage Caused by Others" 101.

276 Van Dam European Tort Law 69; Galand-Carval "Liability for Damage Caused by Others" 90.

277 See Galand-Carval "Liability for Damage Caused by Others" 91.

278 Cass civ 225 February 1998 95-20419, Bull civ 1998 || 62 38, JCP || 10149 note Viney. See Galand-Carval "Liability for Damage Caused by Others" 91.

279 Viney "Tort Liability" 251; Galand-Carval "Liability for Damage Caused by Others" 86. 
property. ${ }^{280}$ In terms of Article $1384(4)$ the parents of a minor ${ }^{281}$ may be held liable jointly and severally 282 for damage caused by their minor child if at the time they exercised "parental authority" over the child; that is, if the child still usually lives with them. ${ }^{283}$ If a child commits a delict while in another person's care, the parents will not escape liability. All that needs to be established is that the child is liable to the plaintiff. Fault on the part of the child is not a requirement. ${ }^{284}$ The parents may still be held liable if the child causes harm to another while at school or on a school outing. ${ }^{285}$ It is not necessary to establish that the child directly caused the harm or loss. ${ }^{286}$ Liability is strict in that the parents cannot raise a defence that "they did not contribute to the child's harmful act by a lack of supervision or a defective education."287 Previously parents were generally not held liable for the conduct of older children if they could establish that there was no faute on their part; that is, if they could prove that there was no failure on their part in supervising the child or no failure on their part in respect of the manner in which the child was brought up. ${ }^{288}$ In most instances the parents were personally at fault but their liability still fell under "responsabilité du fait d'autrui" (liability for the act of another). ${ }^{289}$ But since 1977, stemming from Bertrand $v$ Domingues, ${ }^{290}$ lack of supervision as a requirement was discarded.291 Fault-based liability was changed to so-called objective liability. ${ }^{292}$ Furthermore, stemming from this decision the only defence a parent can rely on is contributory negligence on the part of the plaintiff, or if

\footnotetext{
280 Moréteau "Basic Questions of Tort Law" 66; Van Dam European Tort Law 273.

281 Under eighteen years of age.

282 The joint liability of both the parents was applicable as a result of legislation of 4 June 1970. See Viney "Tort Liability" 252.

283 See Art 1384 (4) of the CC; Cass civ 220 January 2000 98-17005, Bull civ 2000 II 15 10; Van Dam European Tort Law 493; Viney "Tort Liability" 252; Galand-Carval "Liability for Damage Caused by Others" 88-89.

284 See Galand-Carval "Liability for Damage Caused by Others" 89 fn. 14, which refers to an example, Cass civ 29 March 2000 98-18095, Bull civ 2000 II 44 31, where a child injured another child with a pencil he was holding. The parents of the boy holding the pencil were held vicariously liable. Compare Van Gerven, Lever and Larouche Tort Law 521.

285 Galand-Carval "Liability for Damage Caused by Others" 100.

286 Cass Ass plén 9 May 1984 80-93481, Bull crim 1984 164, JCP 1984 II 20255 note Dejean de la Bathie, D 1984525 note Chabas, RTDciv 1984509 observations Huet. See Galand-Carval "Liability for Damage Caused by Others" 89 fn. 15.

287 Galand-Carval "Liability for Damage Caused by Others" 85.

288 Van Dam European Tort Law 494. Compare Viney "Tort Liability" 252; GalandCarval "Liability for Damage Caused by Others" 85.

289 Galand-Carval "Liability for Damage Caused by Others" 85

290 Cass civ 219 February 1997 94-21111, Bull civ 1997 || 56 32, JCP 1997 || 22848.

291 In this case a twelve-year-old boy caused an accident while riding his bicycle. The Cour de Cassation held the boy's parents strictly liable and lack of supervision as a requirement was discarded. See Viney "Tort Liability" 252. Van Gerven, Lever and Larouche Tort Law 523.
} 
there was some external cause to the damage. ${ }^{293}$ Article 1384(4) only applies to the parents, not for example to grandparents, ${ }^{294}$ and there is still uncertainty as to whether it applies to guardians. ${ }^{295}$

The strict liability rule holding the parents liable may apply in instances where: the child committed a faute and an unlawful or wrongful act is sufficient; an "acte objectivement illicite" where the child need not be aware of the unlawfulness of his conduct; ${ }^{296}$ if the damage occurred as a result of a "thing" and the child was the custodian of the thing; 297 and where the child directly caused the damage suffered by the plaintiff. ${ }^{298}$ For example, in one case, ${ }^{299}$ a child injured another child during a rugby game. The child's parents were held liable for the direct causing of injury, even though the child had not committed a faute. Article 1384(7) of the CC, however, states that the parents may not be held liable if they could not have prevented the harmful act. This relates for example to instances such as force majeure 300 or where there is contributory fault on the part of the plaintiff. ${ }^{301302}$

Cass civ 219 February 1997 94-21111, Bull civ 1997 |I 56 32, JCP 1997 II 22848. See Van Dam European Tort Law 493-494; Viney "Tort Liability" 252.

294 In Cass civ 218 March 2004 03-10600, Bull civ 2004 II 140 118, the parents of a ten-year-old child left him in the care of his grandparents and the child set a canister of petrol alight in a shed. The child sustained burns and the parents sued the grandparents for negligent lack of supervision. The Cour de Cassation in terms of Art 1382 of the $C C$ (dealing with personal liability as opposed to strict liability of the parents) dismissed the parents' claim, holding that the child had been staying with his grandparents for over three weeks and was not particularly reckless or undisciplined and therefore did not require special supervision from the grandparents. See Cannarsa 2004 Eur Tort Law Yearb 285-287.

See Cass civ 225 January 1995 92-18802, Bull civ 1995 II 29 17; Van Dam European Tort Taw 493. Galand-Carval "Liability for Damage Caused by Others" 90 refers to Cass Crim 28 March 2000 99-84075, Bull crim 2000140 416, where the guardian was held liable in an instance where the child accidentally shot and killed a playmate with a rifle. Van Dam European Tort Law 494.

297 Cass civ 210 February 1966, D 1966 332. See Van Dam European Tort Law 494.

298 See cases cited by Van Dam European Tort Law $494 \mathrm{fn} 17$.

299 Cass Ass plén 13 December 2002 00-13787, Bull Ass plén 20024 7, D 2003231 note Jourdain. See Brun 2002 Eur Tort Law Yearb 199; Van Dam European Tort Law 494.

300 See Cass civ 219 February 1997 94-21111, Bull civ 1997 II 56 32, JCP 1997 II 22848; Galand-Carval "Liability for Damage Caused by Others" 89.

301 See Cass civ 21 December 1965, JCP 19662 14567; Cass civ 22 December 1998 96-22158, Bull civ 1998292 176; Cass civ 220 April 2000 98-18809, Bull civ 2000 66 46; Cass civ 29 March 2000 (Epoux X v Mutuelle Générale de l'Education Nationale) 98-18095, Bull civ 2000 II 44 31; Cass civ 229 March 2001 98-20721, Bull civ 2001 II 69 46; Ferreira Fundamental Rights and Private Law in Europe 142143 fn. 193.

302 See, for example, in Lacouture $v$ Société Pyrotechnique Industrielle et agricole, Cass civ 24 July 1990 89-15177, Bull civ 1990 II 167 84, a nine-year-old child on ae beach picked up a discarded firework which exploded. The parents of the child sued the 


\section{Comparative conclusions}

Now that an idea has been conveyed of how the reasonable person standard is applied and adjusted depending on the subjective attributes of the actor in the above-mentioned jurisdictions, it is possible to compare the different applications and analyse how the standard is adjusted from the base standard of the reasonable person.

It is apparent that the standard of the reasonable person is objective as well as subjective. It is objective in the sense that it is the uniform standard that is applied in all the jurisdictions mentioned above to test fault in the form of negligence in the general community. It therefore applies generally to cases, testing the parties' conduct against the hypothetical model reasonable person. ${ }^{303}$ As already mentioned, ${ }^{304}$ the subjective part of the reasonable person standard relates to the personal subjective attributes of the actor, such as inter alia his or her age, knowledge, intelligence, experience, skill, physical attributes, and mental capacity, but still tested objectively. ${ }^{305}$ Depending on the jurisdiction the standard applicable may be the reasonable child, the reasonable person with a physical disability, the reasonable professional and so on, where the test is still objective but also subjective when taking into consideration the subjective attributes of the actor.

In all the jurisdictions discussed, the base standard of the reasonable person is not lowered to take into account the particular person's idiosyncrasies. ${ }^{306}$ Furthermore, in all the jurisdictions discussed, where a person is an expert the base standard of the reasonable person is raised, depending on the person's profession, and a reasonable measure of the particular expertise is expected. ${ }^{307}$ In respect of the reasonable expert standard, besides the particular circumstances present at the time of the delict or tort having an effect, the expert is expected to possess the level of skill and diligence at the time of the delict or tort of other members of the

person looking after the child, the "caretaker". The caretaker then submitted that there was faute on the part of the child, but the Cour de Cassation confirmed that there was faute on the part of the caretaker and not the child. The Cour de Cassation held that the child had not been warned by the caretaker that the firework he picked up was dangerous and that the child could not have been aware that it could explode as the fuses for the firework had already been used. See the discussion of this case in Van Gerven, Lever and Larouche Tort Law 337-338. See para 3.3.1 above.

In para 3.3.1 above.

See Dobbs, Hayden and Bublick Hornbook on Torts 222; para 3.3.1 above.

See paras 3.1-3.4 above.

See paras 3.1-3.4 above. 
professional body to which he or she belongs. ${ }^{308}$ In terms of an expert, whether his or her conduct deviated from that of the reasonable expert will depend on whether the professional acted within the scope of his or her functions and whether he or she acted with the necessary care, skill, and diligence expected of the expert under the same circumstances. ${ }^{309}$ In making a careless error such as perforating an intestinal wall while undertaking a routine scope, a professional's conduct is considered unreasonable and may be found negligent. ${ }^{310}$ Where a person professes to have a particular acquired skill or experience, the person will be held to a reasonable degree of such skill or expertise. ${ }^{311}$

In instances where there is a lack of experience, such as in the case of the learner driver, it seems that there is no leniency and the base standard of the reasonable person applies, especially where the lack of skill and experience poses a danger to others. ${ }^{312}$ The rationale for this is that the learner driver undertakes an activity that requires a certain level of skill or knowledge and he or she ought to know that he or she lacks the required skill or knowledge while undertaking the activity. If the learner driver causes harm to another as a result of his or her lack of skill or experience, then the learner driver may be found negligent. ${ }^{313}$ In South African law, however, it seems that where the lack of experience and skill does not pose any danger (as in the examples of the novice golfer or inexperienced young teacher) the base standard of the reasonable person may not be applied but rather lowered, as the inexperienced person may not be expected to display the same level of knowledge and skill as that of the experienced golfer or teacher. ${ }^{314}$ In American law, as already said, ${ }^{315}$ certain statutes may lower the standard of reasonable care of drivers who respond to an emergency, such as police motor vehicles, fire engines and ambulances etcetera. The drivers may disobey the usual traffic rules but must still either drive with reasonable care or not recklessly under the circumstances. In France, according to the loi Badinter, ${ }^{316}$ children under sixteen years of age, a person older than seventy years and a person more than eighty per cent

See paras 3.1-3.4 above.

See para 3.4 above.

See para 3.4 above.

See Woolridge $v$ Sumner 19632 QB 43; para 3.2 above.

See paras 3.1-3.4 above.

See paras 3.1-3.3 above.

See para 3.1 above.

See para 3.3 above.

Law no 85-677 of 5 July 1985. 
incapacitated may not be held contributorily negligent, but it seems that the base standard of the "bonus pater familias" applies to all drivers. ${ }^{317}$

Children are generally held to a more relaxed standard when compared to adults, in that, to begin with, in some jurisdictions very young children cannot be held negligent. ${ }^{318}$ Generally, in English law a very young child such as a child under the age of three, in American law a child under the age of five, and in South African law a child under the age of seven cannot be held negligent or liable in delict or tort. ${ }^{319}$ It is submitted that generally the child's age, intellect, maturity, experience etcetera as subjective factors are considered when judging their conduct. ${ }^{320}$ The subjective factors may be considered directly or indirectly and lend to the more relaxed treatment applied to children, which is reasonable and justifiable. In English law the reasonable child test is applied. ${ }^{321}$ In South African law it must first be considered whether a child can be held accountable. Under accountability, subjective factors such as whether the child can tell the difference between right and wrong, experience, maturity, intellect and so on are considered. ${ }^{322}$ Even though the age of the child may not be referred to (as in American law), ${ }^{323}$ the other subjective factors considered in a sense correlate with the child's age. In American law a child's conduct is tested against that of the reasonable person of his age, intelligence, maturity, and experience in similar circumstances. ${ }^{324}$ In French law the situation is indeed unique in that even though in principle the bonus pater familias standard is applied, the requirement of discernment (which is similar to the concept of accountability) has been dispensed with and the parents are generally held strictly liable for the conduct of children still living with them. ${ }^{325}$ Although the strict liability rule that applies to parents may seem harsh, it is tempered by the fact that almost all French families are protected by liability insurance cover at a minimal cost. ${ }^{326}$ Furthermore, most social institutions are insured against civil liability. ${ }^{327}$ It may be argued, though, that this rule is not really tempered as the parents or institutions have to pay for the insurance, but it

\footnotetext{
317 See Van Gerven, Lever and Larouche Tort Law 314; para 3.4 above.

318 See para 3.1-3.4 above.

319 See para above 3.1-3.3 above.

320 However, in France the requirement of discernment similar to the concept of accountability and capacity has been dispensed with. See para 3.4 above.

See para 3.2 above.

See para 3.1 above.

See para 3.3 above.

See Dobbs, Hayden and Bublick Hornbook on Torts 233; Keeton et al Prosser and Keeton on the Law of Torts 179; para 3.3 above.

325 In terms of Art 1384 of the CC. See para 3.4 above.

326 Van Dam European Tort Law 495.

327 See Galand-Carval "Liability for Damage Caused by Others" 91.
} 
may be understood and regarded as reasonable where it is apparent that France follows a pro-victim approach, ensuring that the plaintiff receives compensation.

In Anglo-American law, if an elderly driver poses a risk of harm to others as a result of his or her declining mental or physical abilities, then he or she is held to the base standard of the reasonable person and may be held negligent. ${ }^{328}$ In France, where the loi badinte ${ }^{329}$ is applicable, contributory negligence as a defence is no longer applicable to an elderly person over seventy years of age. A more relaxed approach seems to apply to plaintiffs only with regard to road accident claims in France and American law. ${ }^{330}$ As already mentioned, ${ }^{331}$ there is also a lack of authority on how the standard of the reasonable person should be applied to the elderly in South African law. It is submitted that in terms of a fair and reasonable common sense approach, the naturally declining physical and cognitive abilities of an elderly person should be considered in lowering the base standard of the reasonable person. This recommendation will be discussed further below. ${ }^{332}$

In respect of persons with physical disabilities or impairments, there seems to be a lack of authority. However, of all the jurisdictions, American law seems to adopt the most sensible approach. Physical disability or impairment may have the effect of either lowering the base standard of the reasonable person or in certain instances exonerating the person from liability. American law specifically refers to the standard of the reasonable person with a similar disability. ${ }^{333}$ This standard is generally applied to persons where there is a loss of a motor function, such as persons who are blind or deaf. In these instances it is apparent that the base standard is lowered, taking into consideration the nature and extent of the disability. Naturally, the conduct of the person with a physical disability or impairment must still be reasonable in the context of his or her knowledge of the

328 See Roberts $v$ Ring 173 NW 437, 438 (Minn 1919); American Law Institute Restatement Third of Torts $2005 \S 9 \mathrm{cmt} \mathrm{c}$; Epstein and Sharkey Cases and Materials on Torts 119; Barett III 1984 J Marshall L Rev 873.

329 Law no 85-677 of 5 July 1985 , which has regulated traffic accidents in France since 5 July 1985.

330 See Barett III $1984 \mathrm{~J}$ Marshall L Rev 889 with regard to American law in some states. $331 \quad$ In para 3.1.

332 See para 5 below.

333 American Law Institute Restatement Third of Torts $2010 \S 11(\mathrm{a})$. See para 3.3 above. 
disability or impairment. ${ }^{334}$ Van der Walt and Midgley ${ }^{335}$ provide a good example of a person who is blind and aware of his physical impairment. In this instance the person will be found negligent if he or she drives a car on the street and causes harm.

In situations where a person suffers some kind of condition or physical disability of which he or she is unaware, such as a heart attack or sudden blackout, and causes harm, in Anglo-American law as well as South African law the person may be exonerated from liability. In Anglo-American law fault is absent as the heart attack or sudden blackout was unforeseeable. ${ }^{336}$ In South African law there is an absence of conduct $^{337}$ as well as fault. ${ }^{338}$ Where a person is aware of his or her condition or can reasonably foresee that he or she is prone to the condition and for example forgets to take his or her medication, which eventually leads to the causing of harm, generally the principle of "prior fault" applies and the person may be held negligent for not controlling the condition. ${ }^{339}$

With regard to persons with mental impairments, of all the jurisdictions South African law seems to have the most lenient approach in that, depending on the circumstances, conduct may be absent ${ }^{340}$ and the base standard of the reasonable person will not even come into play if the person cannot be held accountable. If the person's cognitive and intellectual shortcomings result in him or her not being able to distinguish between right and wrong and act in accordance with such appreciation, then the question of fault does not even arise. ${ }^{341}$ In Anglo-American law a mentally impaired person is judged according to the base standard of the reasonable person despite his or her cognitive and intellectual shortcomings. ${ }^{342}$ The person with the mental impairment is in a sense held strictly liable and even though holding such a person to the base standard of the reasonable person has been criticised, French law seems to offer the most plausible rationale for this approach - that it is fair and reasonable to compensate the innocent plaintiff. ${ }^{343}$ With regard to French law, which generally favours strict liability, the dispensing with the requirement of discernment (which is similar to the

\footnotetext{
$334 \quad R v$ Verster 19522 SA 231 (A) 234; Van der Walt and Midgley Principles of Delict 241.

335 Van der Walt and Midgley Principles of Delict 241. See para 3.1 above.

336 See paras 3.2-3.3 above.

337 As the conduct is not voluntary, see para 3.1 above,

338 See para 3.1 above.

339 Peel and Goudkamp Winfield and Jolowicz on Tort 149. See para 3.1-3.3.

340 If the conduct is deemed involuntary. See para 3.1 above.

341 See para 3.1 above.

342 See para 2 above.

343 See paras 3.2-3.4 above.
} 
concept of accountability), coupled with the fact that most French people take out insurance to cover delictual liability, explains the more claimantbiased approach followed in France as against the South African approach, for instance.

\section{Recommendations for the South African law of delict}

The South African approach to determining the negligence of a person with a mental impairment is commendable, in that the standard of the reasonable person will be applied only if the person can be held accountable. The person's cognitive and intellectual state of mind at the time of the delict are taken into consideration and if he or she cannot be held accountable, then the base standard of the reasonable person is not applied. ${ }^{344}$

South African law follows the same approach as the other jurisdictions discussed in this contribution of raising the base standard of the reasonable person when it comes to experts. All the jurisdictions apply the base standard of the reasonable person where a person is inexperienced and in instances where the risk of harm is high in respect of the activity undertaken, such as in the case of the learner driver. This is understandable when taking into account the foreseeable risk of harm. It is also understandable that in South African law, where the foreseeable risk of harm is not appreciable, as in the example of the novice golfer or the inexperienced young teacher, it may not be fair or reasonable to judge the inexperienced person according to the base standard of the reasonable person. Thus, the base standard of the reasonable person may be lowered to take into consideration the subjective lack of skill, knowledge and experience of the actor. ${ }^{345}$

Concerning children, the applicability of the concept of accountability in South African law is commendable. However, the criticism that a child's conduct cannot realistically be measured against that of an adult should be earnestly noted. ${ }^{346}$ The American approach follows an appealing middle path between the reasonable child standard and the base standard of the reasonable person, in that the standard applied is that of the reasonable person "of his own age, intelligence, and experience in similar circumstances." ${ }^{147}$ The age, level of maturity, knowledge, prior experience, whether he or she can understand the consequences of his or her actions and the surrounding circumstances are taken into consideration in a

\footnotetext{
344 See para 3.1 above.

345 See para 3.1 above.

346 See Neethling and Potgieter Law of Delict 144, para 3.1 above.

347 Dobbs, Hayden and Bublick Hornbook on Torts 233 fn 224.
} 
meaningful manner. ${ }^{348}$ The approach followed in American law in respect of minors could also be followed in South African law. In respect of minors, South African law already applies the concept of accountability as a prerequisite for negligence ${ }^{349}$ and could apply the standard of the reasonable person of his or her age, intellect, level of maturity and experience under similar circumstances. It follows that the minor's conduct is not tested against the base standard of the reasonable person but is lowered to take into account the subjective attributes of the child relating to his or her age, intellect, level of maturity and experience in a more expressive and meaningful way.

In respect of the elderly it is recommended that the base standard of the reasonable person be lowered generally to take into account their naturally declining physical and cognitive abilities. Barrett $1 \mathrm{II}^{350}$ submits that the "characteristics of old age are predictable and capable of diagnosis, ample scientific and medical authority is available" in order to determine the capacity of the elderly person. $\mathrm{He}^{351}$ encourages a more lenient approach to persons from the age of sixty-five years onwards. He explains that once capacity has been established, the standard of the "reasonably careful person of like age and similar infirmities" be applied. $\mathrm{He}^{352}$ submits though that as with children who undertake certain risky activities usually undertaken by adults (such as driving a car), the base standard of the reasonable person should apply to the elderly person under these circumstances unless out of necessity, the elderly person had no other choice but to undertake the risky activity (that is, driving the car under the circumstances). The rationale behind this base standard being applied to minors and the elderly is that driving a car is an inherently dangerous activity and due to the concerns of public interest and safety, society requires an exception to apply in this instance..$^{353}$ Barrett III354 persuasively submits that from a statistical, legal and practical point of view, the law should be reformed to take into account the subjective naturally declining, physical and cognitive abilities of the elderly defendant when determining negligence. The elderly person should generally not be held to the base standard of the reasonable person. It is recommended that South African law should consider applying a more lenient approach when determining the

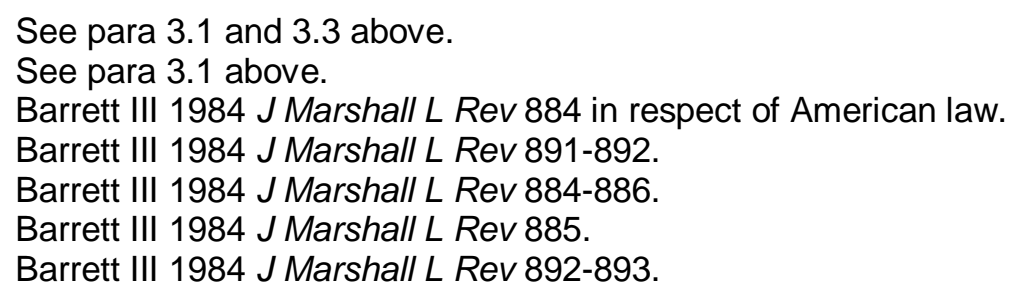


negligence of elderly persons to take into account their naturally declining physical and cognitive abilities. Again, accountability would in any event apply as a prerequisite for negligence. The standard of the reasonable person of like age and similar physical and cognitive abilities or infirmities could be applied to persons over the age of sixty-five years.

In South African law, even though there is a lack of authority on how the standard should apply to persons with physical disabilities, one can see the appeal of the American approach once again, which generally uses the standard of the reasonable person with the same disability. ${ }^{355}$ In effect, the base standard of the reasonable person is lowered to take into account the subjective disability but is still tested objectively. South African law could adopt this approach.

In instances where a person suffers some kind of condition, such as the example of a heart attack where the person was unaware of his or her condition, South African law follows a commendable approach whereby the elements of conduct and fault are called into question. If the conduct was mechanical and involuntary under the circumstances, conduct is lacking and fault is absent unless the principle of "prior fault" applies. ${ }^{356}$

On a final note with regard to the recommendations and possible reform of the application of the standard of the reasonable person in South African law, Moran's $\mathrm{s}^{357}$ concerns regarding our distinction and understanding of the concepts of normal, ordinary and reasonable behaviour should be heeded so as not to lead to any discrimination. Thus ordinary, natural, normal behaviour need not equate to reasonable behaviour in all instances. Furthermore, gender equality should apply and the standard of the reasonable person should be applied in the same manner to all genders.

\section{Bibliography}

\section{Literature}

Ahmed Explicit and Implicit Influence of Reasonableness

Ahmed R The Explicit and Implicit Influence of Reasonableness on the Elements of Delictual Liability (LLD-thesis University of South Africa 2018)

See para 3.3 above.

See para 3.1 above.

Moran Rethinking the Reasonable Person; see paras 2 and 3.2 above. 
Ahmed 2019 PELJ

Ahmed R "The Influence of Reasonableness on the Element of Conduct in Delictual or Tort Liability - Comparative Conclusions" 2019 PELJ 1-34

Ahmed 2019 THRHR

Ahmed $\mathrm{R}$ "The Origins of the Recent New Approach to Determining Wrongfulness in the South African Law of Delict" 2019 THRHR 136-146

Alexander and Szas 1967 Notre Dame L Rev

Alexander GJ and Szas TS "Mental Illness as an Excuse for Civil Wrongs" 1967 Notre Dame L Rev 24-38

American Law Institute Restatement Second of Torts 1965

American Law Institute Restatement Second of Torts (American Law Institute St Paul 1965)

American Law Institute Restatement Second of Torts 1979

American Law Institute Restatement Second of Torts (American Law Institute St Paul 1979)

American Law Institute Restatement Third of Torts 2000

American Law Institute Restatement Third of Torts (Apportionment of Liability) (American Law Institute St Paul 2000)

American Law Institute Restatement Third of Torts 2005

American Law Institute Restatement Third of Torts (Liability for Physical Harm) (American Law Institute St Paul 2005)

American Law Institute Restatement Third of Torts 2010

American Law Institute Restatement Third of Torts (Liability for Physical and Emotional Harm) (American Law Institute St Paul 2010)

Artosi "Reasonableness"

Artosi A "Reasonableness, Common Sense, and Science" in Bongiovanni G, Sartor G and Valentini C Reasonableness and Law (Springer Dordrecht 2009) 69-78

Barett III 1984 J Marshall L Rev

Barett CV III "Negligence and the Elderly: A Proposal for a Relaxed Standard of Care" 1984 J Marshall L Rev 873-894

Bender $1988 \mathrm{~J}$ Leg Ed

Bender L "A Lawyer's Primer on Feminist Theory and Tort" $1988 \mathrm{~J}$ Leg Ed 3-37 
Boberg Law of Delict

Boberg PQR The Law of Delict Volume 1: Aquilian Liability (Juta Cape Town 1984)

Brun 2002 Eur Tort Law Yearb

Brun P "Country Reports: France" 2002 Eur Tort Law Yearb 179-206

Burchell Principles of Delict

Burchell JM Principles of Delict (Juta Cape Town 1993)

Cannarsa 2004 Eur Tort Law Yearb

Cannarsa M "Country Reports: France" 2004 Eur Tort Law Yearb 274-299

Deakin and Adams Markesinis and Deakin's Tort Law

Deakin S and Adams Z Markesinis and Deakin's Tort Law $8^{\text {th }}$ ed (Clarendon Press Oxford 2019)

Dobbs, Hayden and Bublick Hornbook on Torts

Dobbs DB, Hayden PT and Bublick EM Hornbook on Torts $2^{\text {nd }}$ ed (West St Paul 2016)

Donovan and Wildman 1981 Loy LA L Rev

Donovan DA and Wildman SM "Is the Reasonable Man Obsolete? A Critical Perspective on Self-defence and Provocation" 1981 Loy LA L Rev 435-468

Epstein and Sharkey Cases and Materials on Torts

Epstein RA and Sharkey CM Cases and Materials on Torts $11^{\text {th }}$ ed (Aspen Law New York 2016)

Ferreira Fundamental Rights and Private Law in Europe

Ferreira N Fundamental Rights and Private Law in Europe: The Case of Tort Law and Children (Routledge Abingdon 2013)

Fleming Law of Torts

Fleming JG The Law of Torts $9^{\text {th }}$ ed (Law Book Company Sydney 1998)

Galand-Carval "Liability for Damage Caused by Others"

Galand-Carval S "Liability for Damage Caused by Others under French Law" in Spier J (ed) Unification of Tort Law: Liability for Damage Caused by Others (Kluwer Law The Hague 2003) 85-103

Gilligan In a Different Voice

Gilligan C In a Different Voice: Psychological Theory and Women's Development (Harvard University Press Cambridge 1982) 
Green and Cardi "Basic Questions of Tort Law"

Green MD and Cardi WJ "Basic Questions of Tort Law from the Perspective of the USA" in Koziol H (ed) Basic Questions of Tort Law from a Comparative Perspective (Jan Sramek Verlag Vienna 2015) 431-514

Hart Concept of Law

Hart HLA Concept of Law (Oxford University Press Oxford 1961)

Holmes Common Law

Holmes OW The Common Law (MacMillan London 1881)

Jansen and Neethling 2017 THRHR

Jansen R-M and Neethling $J$ "Delictual Capacity and Contributing Negligence of Minors" 2017 THRHR 474-482

Jones "Negligence"

Jones MA "Negligence" in Jones MA (gen ed) Clerk and Lindsell on Torts $21^{\text {st }}$ ed (Sweet \& Maxwell London 2014) 439-607

Keating 1996 Stan L Rev

Keating GC "Reasonableness and Rationality in Negligence Theory" 1996 Stan L Rev 311-384

Keeton et al Prosser and Keeton on the Law of Torts

Keeton $\mathrm{P}$ et al Prosser and Keeton on the Law of Torts $5^{\text {th }}$ ed (West St Paul 1984)

Loubser and Midgley Law of Delict

Loubser MM and Midgley JR (eds) The Law of Delict in South Africa $3^{\text {rd }}$ ed (Oxford University Press Cape Town 2018)

Martin 1994 Anglo-Am L Rev

Martin RM "A Feminist View of the Reasonable Man: An Alternative Approach to Liability in Negligence for Personal Injury" 1994 Anglo-Am L Rev 334-374

McBride and Bagshaw Tort Law

McBride NJ and Bagshaw R Tort Law $6^{\text {th }}$ ed (Pearson Education New York 2018)

Miller and Perry 2012 NYU L Rev

Miller AD and Perry R "The Reasonable Person" 2012 NYU L Rev 323-392 
Moran Rethinking the Reasonable Person

Moran M Rethinking the Reasonable Person: An Egalitarian Reconstruction of the Objective Standard (Oxford University Press Oxford 2003)

Moréteau "Basic Questions of Tort Law"

Moréteau O "Basic Questions of Tort Law from a French Perspective" in Koziol H (ed) Basic Questions of Tort Law from a Comparative Perspective (Jan Sramek Verlag Vienna 2015) 3-98

Moréteau 2007 Eur Tort Law Yearb

Moréteau O "Country Reports: France" 2007 Eur Tort Law Yearb 274-287

Moréteau 2009 Eur Tort Law Yearb

Moréteau O "Country Reports: France" 2009 Eur Tort Law Yearb 198-216

Mullender 2005 MLR

Mullender $\mathrm{R}$ "The Reasonable Person, the Pursuit of Justice, and Negligence Law" 2005 MLR 681-695

Neethling 2002 SALJ

Neethling J "Self-defence: The 'Unreasonable' Reasonable Man" 2002 SALJ 283-287

Neethling and Potgieter Law of Delict

Neethling J and Potgieter JM Law of Delict $8^{\text {th }}$ ed (LexisNexis Durban 2020)

Peel and Goudkamp Winfield and Jolowicz on Tort

Peel E and Goudkamp J Winfield and Jolowicz on Tort 19 ${ }^{\text {th }}$ ed (Sweet \& Maxwell London 2014)

Ripstein "Reasonable Persons in Private Law"

Ripstein A "Reasonable Persons in Private Law" in Bongiovanni G, Sartor $G$ and Valentini $C$ (eds) Reasonableness and Law (Springer New York 2009) 253-281

Sappideen and Vines Fleming's The Law of Torts

Sappideen C and Vines P (eds) Fleming's The Law of Torts $10^{\text {th }}$ ed (Law Book Company Sydney 2011)

Scott 2014 De Jure

Scott TJ "Loureiro and Others v iMvula Quality Protection (Pty) Ltd 20143 SA 394 (SCA): Determination of Constitutional Nature of Contractual and Delictual Claims" 2014 De Jure 374-392 
Van Dam European Tort Law

Van Dam C European Tort Law $2^{\text {nd }}$ ed (Oxford University Press Oxford 2013)

Van der Walt and Midgley Principles of Delict

Van der Walt JC and Midgley JR Principles of Delict $4^{\text {th }}$ ed (LexisNexis Durban 2016)

Van Gerven, Lever and Larouche Tort Law

Van Gerven W, Lever JF and Larouche P Tort Law (Hart Oxford 2000)

Viney "Tort Liability"

Viney G "Tort Liability" in Bermann GA and Picard E (eds) Introduction to French Law (Kluwer Law The Hague 2012) 237-261

Visser "Compensation for Pecuniary Loss"

Visser D "Compensation for Pecuniary Loss - Actio Legis Aquiliae" in Du Bois F (ed) Wille's Principles of South African Law $9^{\text {th }}$ ed (Juta Cape Town 2007) $1094-1160$

Vogel "Is Citizenship Gender-specific?"

Vogel U "Is Citizenship Gender-specific?" in Vogel U and Moran M The Frontiers of Citizenship (MacMillan London 1991) 58-85

Weinrib Tort Law

Weinrib EJ Tort Law: Cases and Materials (Emond Montgomery Toronto 1997)

Welke Recasting American Liberty

Welke BY Recasting American Liberty (Cambridge University Press New York 2001)

Witting Street on Torts

Witting CA Street on Torts $15^{\text {th }}$ ed (Oxford University Press Oxford 2017)

Zipursky 2004 Fordham L Rev

Zipursky BC "Rawls in Tort Theory: Themes and Counter-Themes" 2004 Fordham L Rev 1923-1940

Zipursky 2015 U Pa L Rev

Zipursky BC "Reasonableness in and out of Negligence Law" 2015 U Pa L Rev 2131-2170 
Zweigert and Kötz Introduction to Comparative Law

Zweigert $\mathrm{K}$ and Kötz $\mathrm{H}$ Introduction to Comparative Law $3^{\text {rd }}$ ed (Clarendon Press Oxford 2011)

Case law

Australia

Adamson v Motor Vehicle Insurance Trust 195758 WALR 56 (SC)

Cook v Cook 198668 ALR 353

McHale v Watson 1966115 CLR 199 (Aust HC)

McNeilly $v$ Imbree 2008 HCA 40

\section{Canada}

Coley v CPR 190629 (Que SC)

Lengyel v Manitoba Power Commission 195712 DLR 2d 126 (Man CA)

Michaud v Dupuis 197720 NBR 2d 305 (QB)

Pollock v Lipkowitz 197017 DLR 3d 766 (Man QB)

\section{France}

CA Paris 6 June 1959, D 195976

Cass Ass plén 9 May 1984 80-93481, Bull crim 1984 164, JCP 1984 II 20255 note Dejean de La Bathie, D 1984525 note Chabas RTDciv 1984 509 observations Huet

Cass Ass plén 29 March 1991 89-15231, Bull Ass plén 19911 1, D 1991 Jur 324 note Larroumet, JCP 1991 II 21673, conclusions Dontenwille note Ghestin, Gaz Pal 1991 Jur 513 note Chabas

Cass Ass plén 13 December 2002 00-13787, Bull Ass plén 20024 7, D 2003231 note Jourdain

Cass civ 18 June 1896, S 1897117 note Esmein, D 18971 4333, note Saleilles

Cass civ 120 May 1936 (Mercier), DP I 88 
Cass civ 120 July 1976 74-10238, Bull civ 1976 I 270218

Cass civ 19 November 2004 01-17908, Bull civ 2004 I 262219

Cass civ 129 November 2005 03-16308, Bull civ 2005 | 456383

Cass civ 118 September 2008 07-12170; Bull civ 2008 I 205

Cass civ 118 September 2008 07-13080, Bull civ 2008 I 206

Cass civ 28 February 1962, Bull civ 1962 II 180

Cass civ 21 December 1965, JCP 1966214567

Cass civ 215 December 1965, D 1966 Jur 397

Cass civ 210 February 1966, D 1966332

Cass civ 24 February 1981 79-11243, Bull civ 1981 II 21, JCP 1981 IV 136

Cass civ 212 December 1984 82-12627, Bull civ 1984 II 193

Cass civ 23 July 1991 90-13158, Bull civ 1991 II 210111

Cass civ 225 January 1995 92-18802, Bull civ 1995 II 2917

Cass civ 219 February 1997 94-21111, Bull civ 1997 II 56 32, JCP 1997 II 22848

Cass civ 225 February 1998 95-20419, Bull civ 1998 II 62 38, JCP II 10149 note Viney

Cass civ 22 December 1998 96-22158, Bull civ 1998292176

Cass civ 220 January 2000 98-17005, Bull civ 2000 II 1510

Cass civ 29 March 2000 98-18095, Bull civ 2000 II 4431

Cass civ 29 March 2000 (Epoux X v Mutuelle Générale de l'Education Nationale) 98-18095, Bull civ 2000 II 4431

Cass civ 220 April 2000 98-18809, Bull civ 20006646

Cass civ 229 March 2001 98-20721, Bull civ 2001 II 6946

Cass civ 218 March 2004 03-10600, Bull civ 2004 II 140118 
Cass crim 26 March 1997 95-83957, Bull crim 1997124 414, JCP 1997 II 22868

Cass crim 28 March 2000 99-84075, Bull crim 2000140416

Lacouture v Société Pyrotechnique Industrielle et agricole, Cass civ 24 July 1990 89-15177, Bull civ 1990 II 16784

TGI St Etienne 15 May 1974, Gaz Pal 1976109

\section{South Africa}

Clark v Welsh 19763 SA 484 (A)

Eskom Holdings Ltd v Hendricks 20055 SA 503 (SCA)

Esterhuizen v Administrator, Transvaal 19573 SA 710 (T)

Hafajee v South African Railways and Harbours 19813 SA 1062 (W)

Herschel v Mrupe 19543 SA 464 (A)

iMvula Quality Protection v Loureiro 20133 SA 407 (SCA)

Jacobs v Chairman, Governing Body, Rhodes High School 20111 SA 160 (WCC)

Jones v Santam Bpk 19652 SA 542 (A)

Kruger v Coetzee 19662 SA 428 (A)

Louwrens v Oldwage 20061 All SA 197 (SCA)

Lymbrey $v$ Jefferies 1925 AD 236

Medi-Clinic Ltd v Vermeulen 20151 SA 241 (SCA)

Minister of Safety and Security v Carmichele 20043 SA 305 (SCA)

Mukheiber v Raath 19993 SA 1065 (SCA)

$R v$ Verster 19522 SA 231 (A)

Roxa v Mtshayi 19753 SA 761 (A)

S v Campher 19871 SA 940 (A) 
S v Chretien 19811 SA 1097 (A)

S v Laubscher 19981 SA $163(\mathrm{~A})$

Sea Harvest Corporation (Pty) Ltd v Duncan Dock Cold Storage (Pty) Ltd 20001 SA 827 (SCA)

Simon's Town Municipality v Dews 19931 SA 191 (A)

Van Wyk v Lewis 1924 AD 438

Weber v Santam Versekeringsmaatskappy Bpk 19831 SA 381 (A)

\section{United Kingdom}

Blake v Galloway 20041 WLR 284

Bolam v Friem Hospital 19571 WLR 582

Bolitho v City Hackney Health Authority 1998 AC 232

Cooke v Midland Great Western Railway of Ireland 1909 AC 229 (HL)

Glasgow Corporation v Muir 1943 AC 488

Gough v National Coal Board 19532 All ER 1283 (CA)

Hanbury v Hanbury 18928 TLR 559

Mansfield v Weetabix 19881 WLR 1263

Maynard v West Midlands RHA 19841 WLR 634

Morris v Marsden 19521 All ER 925

Mullin v Richards 19981 All ER 920 (CA); 19981 WLR 1304

Nettleship v Weston 19712 QB 691

Orchard v Lee 2009 PIQR P16

Philips v William Whitely Ltd 19381 All ER 566

Roberts v Ramsbottom 19801 All ER 7 (QBD); 19801 WLR 823

Roe v Minister of Health 19542 QB 66 
Sidaway v Bethlem Royal Hospital 1985 AC 871

Vaughan v Menlove 18373 Bing NC 468; 132 ER 490 (CP)

Wilsher v Essex Area Health Authority 1987 QB 730

Wells v Cooper 19582 QB 265

Woolridge v Sumner 19632 QB 43

\section{United States of America}

Adams v Lopez 407 P 2d 50 (NM 1965)

Baker v Joyal 4 AD 3d 596, 771 NYS 2d 269 (2004)

Blakes v Blakes 517 So 2d 444 (La Ct App 1987)

Dellwo v Pearson 259 Minn 452, 107 NW 2d 859, 97 ALR 2d 866 (1961)

Dorais v Paquin 113 NH 187, 304 A 2d 369 (1973)

Fields v Senior Citizens Ctr Inc 528 So 2d 573, 581 (La Ct App 1988)

Fink v City of New York 206 Misc 79, 132 NYS 2d 172 (Sup Ct 1954)

First Nat'l Bank of Ariz v Dupree 136 Ariz 296, 665 P 2d 1018 (Ct App 1983)

Frazier v Common Wealth 845 A 2d 253, 260 (Pa Commw Ct 2004)

Frechette $v$ Welch (1st Cir 1980) 621 F 2d 11

Goodfellow v Coggburn 98 Idaho 202, 203-204, 560 P 2d 873 (1977)

Goodrich v Blair 132 Ariz 459, 646 P 2d 890 (1982)

Gossett v Jackson 249 Va 549, 457 SE 2d 97 (1995)

Hancock-Underwood v Knight 670 SE 2d 720 (Va 2009)

Horton v Hinley 261 Ga 863, 413 SE 2d 199 (1992)

Howle v PYA/Monarch Inc 288 SC 586, 344 SE 2d 157 (1986)

Hudson v Old Guard Ins 3 A 3d 246 (Del 2010)

Jackson v McCuiston 448 SW 2d 33 (Ark 1969) 
Lafayette Par Sch Bd v Cormier ex rel Cormier 901 So 2d 1197 (La Ct App 2005)

Lehmuth v Long Beach Unified Sch Dist 53 Cal 2d 544, 348 P 2d 887, 2 Cal Rptr 279 (1960)

Lenard v Dilley 805 So 2d 175 (La 2002)

Lugtu v Cal Highway Patrol 26 Cal 4th 703, 110 Cal Rptr 2d 528, 28 P 3d 249 (2011)

Lutzkovitz v Murray 339 A 2d 64, 93 ALR 3d 321 (Del 1975)

Massey v Scripter 1977401 Mich 385, 258 NW 2d 44

Mastland Inc v Evans Furniture Inc 498 NW 2d 682 (Iowa 1993)

McGuire v Almy 8 NE 2d 760 (Mass 1936)

McNeely v M \& M Supermarkets Inc 1980154 Ga App 675, 269 SE 2d 483

Michigan Central Railroad v Hassenyer 48 Mich 205, 209-210 (SC 1882)

Moore v Preenell 197738 Md App 243, 379 A 2d 1246

Polmatier v Russ 537 A 2d 468 (Conn 1988)

Price v Kitsap Transit 125 Wash 2d 456, 886 P 2d 556 (1994)

Pritchard v Veterans Cab Co 63 Cal 2d 727, 408 P 2d 360, 47 Cal Rptr 904 (1965)

Purtle v Shelton 474 SW 2d 123 (Ark 1971)

Queen Ins v Hammond 374 Mich 655, 132 NW 2d 792 (1965)

Roberts v Ring 173 NW 437, 438 (Minn 1919)

Robins v City of Wichita 285 Kan 455, 172 P 3d 1187 (2007)

Robinson v Lindsay 92 Wash 2d 410, 598 P 2d 392 (1979)

Savage Indus v Duke 598 So 2d 856 (Ala 1992)

Sinai v Polinger Co 498 A 2d 520 (DC 1985) 
St Mary's Hosp Inc v Bynum, Ark 1978573 SW 2d 914

Steele $v$ Holiday Inns Inc 626 So 2d 593 (Miss 1993)

Stewart v Jefferson Plywood Co 1970255 Or 603, 469 P 2d 783

Swenson Trucking \& Excavating Inc $v$ Truckweld Equipment Co Alaska 1980604 P 2d 1113

Torres v City of Los Angeles 58 Cal 2d 35, 372 P 2d 906, 22 Cal Rptr 866 (1962)

Trentacoast v Brussel 198082 NJ 214, 412 A 2d 436

Williams v Kearby 775 P 2d 670 (Kan App 1989)

\section{Legislation}

\section{France}

French Civil Code of 1804

Law no 68-5 of 3 January 1968

Law no 85-677 of 5 July 1985

Law no 2007-308 5 March 2007

\section{South Africa}

Child Justice Act 75 of 2008

Child Justice Amendment Bill of 2019

\section{LIST OF ABBREVIATIONS}

Anglo-Am L Rev

CC

Eur Tort Law Yearb

Fordham L Rev

$J$ Leg Ed

J Marshall L Rev

Loy LA L Rev

MLR

Notre Dame L Rev
Anglo-American Law Review

French Civil Code of 1804

European Tort Law Yearbook

Fordham Law Review

Journal of Legal Education

John Marshall Law Review

Loyola of Los Angeles Law Review

Modern Law Review

Notre Dame Law Review 
NYU L Rev

PELJ

SALJ

Stan L Rev

THRHR

U Pa L Rev
New York University Law Review

Potchefstroom Electronic Law Journal South African Law Journal

Stanford Law Review

Tydskrif vir Hedendaagse RomeinsHollandse Reg

University of Pennsylvania Law Review 